Article

\title{
The Effect of $\mathrm{CeO}_{2}$ Preparation Method on the Carbon Pathways in the Dry Reforming of Methane on $\mathrm{Ni} / \mathrm{CeO}_{2}$ Studied by Transient Techniques
}

\author{
Constantinos M. Damaskinos ${ }^{1}\left(\mathbb{D}\right.$, Michalis A. Vasiliades $^{1}\left(\mathbb{D}\right.$, Vassilis N. Stathopoulos ${ }^{2}(\mathbb{D}$ and \\ Angelos M. Efstathiou ${ }^{1, *}$ \\ 1 Heterogeneous Catalysis Laboratory, Chemistry Department, University of Cyprus, Nicosia 2109, Cyprus \\ 2 Laboratory of Chemistry and Materials Technology, General Department, School of Sciences, National and \\ Kapodistrian University of Athens, GR-34400 Athens, Greece \\ * Correspondence: efstath@ucy.ac.cy; Tel.: +357-22-892776
}

Received: 30 May 2019; Accepted: 18 July 2019; Published: 21 July 2019

\begin{abstract}
The present work discusses the effect of $\mathrm{CeO}_{2}$ synthesis method (thermal decomposition (TD), precipitation (PT), hydrothermal (HT), and sol-gel (SG)) on the carbon pathways of dry reforming of methane with carbon dioxide (DRM) applied at $750{ }^{\circ} \mathrm{C}$ over $5 \mathrm{wt} \% \mathrm{Ni} / \mathrm{CeO}_{2}$. In particular, specific transient and isotopic experiments (use of ${ }^{13} \mathrm{CO},{ }^{13} \mathrm{CO}_{2}$, and ${ }^{18} \mathrm{O}_{2}$ ) were designed and conducted in an attempt at providing insights about the effect of support's preparation method on the concentration ( $\mathrm{mg} \mathrm{g}_{\mathrm{cat}}{ }^{-1}$ ), reactivity towards oxygen, and transient evolution rates $\left(\mu \mathrm{mol} \mathrm{g}_{\mathrm{cat}}{ }^{-1} \mathrm{~s}^{-1}\right)$ of the inactive carbon formed under (i) $\mathrm{CH}_{4} / \mathrm{He}$ (methane decomposition), (ii) $\mathrm{CO} / \mathrm{He}$ (reverse Boudouard reaction), and (iii) the copresence of the two $\left(\mathrm{CH}_{4} / \mathrm{CO} / \mathrm{He}\right.$, use of $\left.{ }^{13} \mathrm{CO}\right)$. Moreover, important information regarding the relative contribution of $\mathrm{CH}_{4}$ and $\mathrm{CO}_{2}$ activation routes towards carbon formation under DRM reaction conditions was derived by using isotopically labelled ${ }^{13} \mathrm{CO}_{2}$ in the feed gas stream. Of interest was also the amount, and the transient rate, of carbon removal via the participation of support's labile active oxygen species.
\end{abstract}

Keywords: DRM; nickel; cerium dioxide; transient experiments; lattice oxygen; isotopes

\section{Introduction}

Nowadays, a great academic and research interest is seen aimed at exploring the gradual replacement of conventional fossil fuels towards energy production through the utilization of alternative and renewable energy sources such as Natural Gas (NG) and Bio-Gas (BG). The driving force behind it are the findings of NG reservoirs rich in $\mathrm{CO}_{2}(>40 \mathrm{vol} \%)$ [1-3] and renewable bio-gas [4,5], which can be used in the development of technologies, such as the dry reforming of methane (DRM: $\mathrm{CH}_{4}+\mathrm{CO}_{2} \rightarrow 2 \mathrm{CO}+2 \mathrm{H}_{2}$, $\Delta \mathrm{H}^{0}=+261 \mathrm{~kJ} \mathrm{~mol}^{-1}$ ), as more environmentally friendly processes in many aspects [6]. The latter is enforced as it uses two major greenhouse gases $\left(\mathrm{CH}_{4}\right.$ and $\left.\mathrm{CO}_{2}\right)$, while at the same time produces a favorable $\mathrm{H}_{2} / \mathrm{CO}$ gas ratio ( 1) for the Fischer-Tropsch $[7,8]$ synthesis towards liquid fuels, but also for other processes in the production of chemicals (DME, $\mathrm{MeOH}$, ammonia) $[9,10]$. In addition, the low operational cost of DRM in comparison with the already used steam methane reforming (SMR) and partial oxidation of methane (POM) technologies, makes its use very attractive [11-14]. However, the main obstacle for the development of an industrial DRM technology is the catalyst's deactivation due to carbon accumulation, especially over Ni-supported [15] solids, which are mainly used due to their low cost and wide availability. The formation of inactive carbon, in the form of filaments, graphite, and whiskers, mainly is derived from the $\mathrm{CH}_{4}$ decomposition $\left(\mathrm{CH}_{4} \rightarrow \mathrm{C}-\mathrm{s}+2 \mathrm{H}_{2}, \Delta \mathrm{H}^{0}=+75 \mathrm{~kJ} \mathrm{~mol}^{-1}\right)$ and Boudouard reaction $\left(2 \mathrm{CO} \rightarrow \mathrm{C}-\mathrm{s}+\mathrm{CO}_{2}, \Delta \mathrm{H}^{0}=-172 \mathrm{~kJ} \mathrm{~mol}^{-1}\right)$. Thus, the design of a suitable Ni-based catalyst 
supported on reducible metal oxides emerged (e.g., use of $\mathrm{CeO}_{2}, \mathrm{Zr}^{4+}$, $\mathrm{Pr}^{3+}$-, $\mathrm{Ti}^{4+}$-doped $\mathrm{CeO}_{2}, \mathrm{La}_{2} \mathrm{O}_{3}$, $\mathrm{Nb}_{2} \mathrm{O}_{5}$ ) [16-25] since the latter supports possess oxygen storage capacity (OSC), oxygen vacancies, and high oxygen mobility, leading to carbon gasification rates that significantly reduce carbon accumulation rates, but also provide high thermal stability for the supported $\mathrm{Ni}$ catalysts [26,27]. The Ce-based materials owe their advantages against non-reducible metal oxides to the undergoing of fast change in the $\mathrm{Ce}^{4+} \leftrightarrow$ $\mathrm{Ce}^{3+}$ oxidation state (redox behavior), leading to an oxygen release, and vice versa to an oxygen storage, in the ceria-based stable crystal structure [28,29].

Several studies reveal the effect of preparation method of $\mathrm{CeO}_{2}$ nanoparticles for use in a wide variety of applications, and they argue that such solids form different surface defects by exhibiting more surface atoms than their bulk counterparts [30-36]. Such nanoparticles could have various morphological and structural differences (nanorods, nanowires, nano-cubes, etc.) with different surface area, pore volume, and mean pore diameter, thus the synthesis method seems to play an important role [37-41].

In spite of recent efforts to develop suitable $\mathrm{CeO}_{2}$-supported Ni catalysts exhibiting high DRM catalytic activity and carbon resistance [42], fundamental understanding of the effect of support synthesis method on the contribution of the carbon deposition and removal routes has not been reported yet, to the best of our knowledge. The synthesis of $\mathrm{CeO}_{2}$ via different methods $[43,44]$ could lead to several variations in its physicochemical properties, but also to the metal surface when ceria is used as support. The latter is well demonstrated as due to the existence of strong metal support interactions (SMSI) between Ni particles and $\mathrm{CeO}_{2}[45,46]$.

Transient methods (step-gas switches, use of isotopes, and temperature programmed oxidation or hydrogenation) performed over supported metal catalysts provided important information about the carbon paths in the DRM reaction, and relationships between the catalytic activity and coke formation. Furthermore, rival reaction mechanisms and rate determined steps (RDS) under DRM reaction conditions (working catalyst surface) can be elucidated. For example, Schuurman and Mirodatos [47] suggested that on $\mathrm{Ni} / \mathrm{SiO}_{2}$ catalyst the $\mathrm{RDS}$ is the recombination of atomic $\mathrm{C}$ (derived from $\mathrm{CH}_{4}$ dissociation) and atomic $\mathrm{O}$ (derived from $\mathrm{CO}_{2}$ dissociation) over the Ni surface. On the other hand, Slagtern et al. [48] observed that on $\mathrm{Ni} / \mathrm{La}_{2} \mathrm{O}_{3}$ catalyst, $\mathrm{CH}_{4}$ is activated on $\mathrm{Ni}$ as opposed to $\mathrm{CO}_{2}$, which is activated on $\mathrm{La}_{2} \mathrm{O}_{3}$ support (or metal-support interface) towards carbonate-like species formation. Advanced kinetic and mechanistic studies to elucidate the carbon paths in DRM with the use of isotopes $\left(\mathrm{C}^{18} \mathrm{O}_{2},{ }^{13} \mathrm{CH}_{4},{ }^{13} \mathrm{CO}_{2}\right)$ were recently performed to a large extent by our group [17-20,46], but also in some other works [47,49-51]. In these works, the significant participation of lattice oxygen of reducible metal oxide supports (e.g., doped ceria-based materials) towards removal of carbon to form $\mathrm{CO}$ was proved experimentally by ${ }^{18} \mathrm{O}$ transient isotopic experiments followed by DRM reaction. Also, the quantification of origin of carbon $\left(\mathrm{CH}_{4} \mathrm{vs}\right.$. $\mathrm{CO}_{2}$ activation route) was probed as a function of reaction $\mathrm{T}$ and catalyst composition.

The present work aims to address the effect of $\mathrm{CeO}_{2}$ support synthesis method on the carbon pathways in the dry reforming of methane over $5 \mathrm{wt} \% \mathrm{Ni} / \mathrm{CeO}_{2}$ catalysts, where this is reported for the first time to our knowledge. Of particular interest was to investigate differences on (i) the concentration of inactive carbon and its reactivity towards oxygen, (ii) the relative contribution of $\mathrm{CH}_{4}$ and $\mathrm{CO}_{2}$ activation routes to the total carbon formation on the catalytic surface via methane decomposition and Boudouard reactions, and (iii) the participation of labile support's lattice oxygen towards carbon removal, and to what extent. For this purpose, various transient and isotopic experiments followed by temperature programmed oxidation (TPO) were performed.

\section{Results}

\subsection{Catalysts Surface Texture and Structural Properties}

The BET specific surface area (SSA, $\left.\mathrm{m}^{2} \mathrm{~g}^{-1}\right)$, mean pore diameter $\left(\mathrm{d}_{\mathrm{p}}, \mathrm{nm}\right)$, and the specific pore volume $\left(\mathrm{V}_{\mathrm{p}}, \mathrm{cm}^{3} \mathrm{~g}^{-1}\right)$ of the four $\mathrm{CeO}_{2}$ solid supports prepared by different methods, namely: Thermal 
decomposition (TD), precipitation (PT), hydrothermal (HT), and sol-gel (SG), are given in Table S1 (Electronic Supplementary Information, ESI). The SSA was found to be in the $5.6-50 \mathrm{~m}^{2} \mathrm{~g}^{-1}$ range, the $d_{p}$ in the $6.7-22.5 \mathrm{~nm}$ range, and the $\mathrm{V}_{\mathrm{p}}$ in the $0.029-0.203 \mathrm{~cm}^{3} \mathrm{~g}^{-1}$ range. The $\mathrm{CeO}_{2}-\mathrm{HT}$ solid exhibited the largest value of SSA and $V_{P}\left(50 \mathrm{~m}^{2} \mathrm{~g}^{-1}, 0.203 \mathrm{~cm}^{3} \mathrm{~g}^{-1}\right)$, and a pore size of $d_{p}=15.8 \mathrm{~nm}$, as opposed to $\mathrm{CeO}_{2}-\mathrm{PT}\left(5.6 \mathrm{~m}^{2} \mathrm{~g}^{-1}, 0.032 \mathrm{~cm}^{3} \mathrm{~g}^{-1}\right)$ with the largest pore size $(22.5 \mathrm{~nm})$. The powder XRD diffractograms of $5 \mathrm{wt} \% \mathrm{Ni}$ supported on the various $\mathrm{CeO}_{2}$ solid supports are given in Figure $\mathrm{S} 1$. The $\mathrm{CeO}_{2}$ support exhibits the cubic structure [46], and after using the Scherrer equation and the $\mathrm{CeO}_{2}$ (111) diffraction line, the mean primary crystal size $\left(\mathrm{d}_{\mathrm{C}}, \mathrm{nm}\right)$ of support was estimated. Similarly, after using the $\mathrm{NiO}(111)$ diffraction line, the particle size $\left(\mathrm{d}_{\mathrm{NiO}}, \mathrm{nm}\right)$ of $\mathrm{NiO}$ was also estimated. The latter value was then used to estimate the particle size $\left(\mathrm{d}_{\mathrm{Ni}}, \mathrm{nm}\right)$ of $\mathrm{Ni}^{0}$ via Equation (3), and the obtained results are reported in Table S1. There was not any shift of the NiO (111) $2 \theta$ diffraction peak (see Figure S1B) among the different samples, however, variations of the mean Ni particle size $(8.4-20.8 \mathrm{~nm})$ and the mean primary crystal size of ceria support $(11.5-43.1 \mathrm{~nm}$ ) were observed (Table S1). The latter results find good support by the literature as will be discussed in Section 3.1.

\section{2. $\mathrm{H}_{2}$ Temperature-Programmed Desorption $\left(\mathrm{H}_{2}-\mathrm{TPD}\right)$}

Figure 1 presents $\mathrm{H}_{2}$-TPD traces of the $5 \mathrm{wt} \% \mathrm{Ni}$ supported on the various $\mathrm{CeO}_{2}$ solids. It is clearly seen that the $\mathrm{CeO}_{2}$ preparation method resulted in drastic changes of the $\mathrm{H}_{2}$ desorption kinetic features in terms of strength of hydrogen binding states $\left(\mathrm{T}_{\mathrm{M}}\right.$, peak maximum temperature) and their corresponding surface coverage (area under a given desorption peak). Thus, the different preparation method of $\mathrm{CeO}_{2}$ support followed by the same $\mathrm{Ni}$ deposition method (wet impregnation) led to differences in the heterogeneity of the Ni surface (e.g., distribution of strength of hydrogen chemisorption sites on surface $\mathrm{Ni}$ ). In the low-temperature range of $50-200{ }^{\circ} \mathrm{C}$, the amount of $\mathrm{H}_{2}$ desorbed $\left(\mu \mathrm{mol} \mathrm{g}{ }^{-1}\right)$ was significantly larger for $\mathrm{CeO}_{2}-\mathrm{HT}\left(23.8 \mu \mathrm{mol} \mathrm{g}^{-1}\right)$ compared to the other three ceria-supported $\mathrm{Ni}$ catalysts $\left(\mathrm{CeO}_{2}-\mathrm{PT}\right.$, $-\mathrm{TD}$, and $\left.-\mathrm{SG}\right)$, where similar amounts were found $(8.8,8.0$, and $6.2 \mu \mathrm{mol} \mathrm{g}{ }^{-1}$, respectively). In the high-temperature range of $200-500{ }^{\circ} \mathrm{C}$, the amount of $\mathrm{H}_{2}$ desorbed follows a different order: $\mathrm{Ni} / \mathrm{CeO}_{2}-\mathrm{TD}\left(25.3 \mu \mathrm{mol} \mathrm{g}^{-1}\right)>\mathrm{Ni} / \mathrm{CeO}_{2}-\mathrm{PT}\left(17.3 \mu \mathrm{mol} \mathrm{g}^{-1}\right)>\mathrm{Ni} / \mathrm{CeO}_{2}-\mathrm{HT}$ $\left(17 \mu \mathrm{mol} \mathrm{g}^{-1}\right)>\mathrm{Ni} / \mathrm{CeO}_{2}-\mathrm{SG}\left(8.5 \mu \mathrm{mol} \mathrm{g}^{-1}\right)$. Of interest is the fact that all ceria-supported $\mathrm{Ni}$ catalysts present three main desorption peaks. However, shoulders to these main desorption peaks appear at different temperatures. For example, the $\mathrm{Ni} / \mathrm{CeO}_{2}-\mathrm{TD}$ presents three main desorption peaks centered at 57,222 , and $354^{\circ} \mathrm{C}$ with shoulder at the falling part of the 3rd peak (Figure 1a), Ni/CeO $-\mathrm{PT}$ at 57, 303 , and $393{ }^{\circ} \mathrm{C}$ with clear shoulders at the falling part of the 1st peak, the rising part of 2nd peak, and the falling part of $3 \mathrm{rd}$ peak (Figure $1 \mathrm{~b}$ ). Ni/ $\mathrm{CeO}_{2}-\mathrm{HT}$ presents the three main desorption peaks centered at 95,258 , and $362^{\circ} \mathrm{C}$ with shoulders at the falling part of 3nd peak (Figure 1c), whereas Ni/CeO ${ }_{2}-\mathrm{SG}$ at 79,157 , and $383^{\circ} \mathrm{C}$ with shoulders at the low-T side of 3nd peak (Figure 1d).

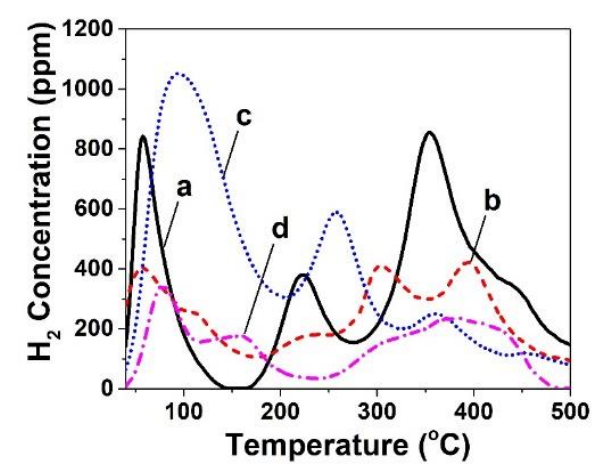

Figure 1. $\mathrm{H}_{2}$ temperature-programmed desorption $\left(\mathrm{H}_{2}-\mathrm{TPD}\right)$ traces obtained over $5 \mathrm{wt} \% \mathrm{Ni} / \mathrm{CeO}_{2-\delta}$ catalysts prepared by (a) Thermal Decomposition (TD), (b) Precipitation (PT), (c) Hydrothermal (HT), and (d) Sol Gel (SG) method; $\mathrm{F}_{\mathrm{He}}=50 \mathrm{NmL} \mathrm{min}^{-1} ; \beta=30^{\circ} \mathrm{C} \mathrm{min}^{-1} ; \mathrm{W}=0.3 \mathrm{~g}$. 
The Ni dispersion $\left(\mathrm{D}_{\mathrm{Ni}}, \%\right.$ ) of the given solids was estimated based on the total amount of $\mathrm{H}_{2}$ desorbed (Figure 1), and results are presented in Table S1 (ESI). The lowest dispersion of Ni was found when $\mathrm{CeO}_{2}$-SG was used as support (3.4\%), followed by the $\mathrm{CeO}_{2}-\mathrm{PT}(6.1 \%), \mathrm{CeO}_{2}-\mathrm{TD}(7.8 \%)$, and the $\mathrm{CeO}_{2}-\mathrm{HT}\left(9.6 \%\right.$, highest dispersion). Thus, the Ni particle size $\left(\mathrm{d}_{\mathrm{Ni}}, \mathrm{nm}\right)$ estimated via Equation (4) was found to be: $10.1,12.4,15.9$, and $28.5 \mathrm{~nm}$ for the $\mathrm{CeO}_{2}-\mathrm{HT}$, -TD, -PT, and -SG, respectively. The latter results were supported by those obtained from the powder XRD analyses (Section 2.1, Figure S1 and Table S1) and the HR-TEM (Section 2.3), but also with those reported previously [20].

\subsection{Transmission Electron Microscopy (TEM) Studies}

HR-TEM images obtained over the fresh $5 \mathrm{wt} \% \mathrm{Ni} / \mathrm{CeO}_{2}-\mathrm{HT}$ (the support was prepared by the hydrothermal method, HT) calcined in air for $4 \mathrm{~h}$ at $750{ }^{\circ} \mathrm{C}$ are given in Figure S2 (ESI). It is seen that dispersed Ni nanoparticles of $\sim 8-12 \mathrm{~nm}$ in size were observed, in good agreement with the $\mathrm{H}_{2}$-TPD and powder XRD results.

\subsection{Scanning Electron Microscopy (SEM) Studies}

SEM images obtained over the fresh $\mathrm{CeO}_{2}$-supported Ni solids are presented in Figure S3 (ESI). The secondary particle size (agglomerates) of the catalyst's support was in the range of $10-50 \mathrm{~nm}$, where different porous structures were derived after using the four different $\mathrm{CeO}_{2}$ synthesis methods.

\subsection{Catalytic Performance Studies in DRM}

Figure 2A presents catalytic performance results in terms of specific integral rate $\left(\mathrm{mol} \mathrm{g}_{\mathrm{cat}}{ }^{-1} \mathrm{~min}^{-1}\right)$ of $\mathrm{CH}_{4}$ conversion and $\mathrm{H}_{2} / \mathrm{CO}$ gas product ratio obtained after $30 \mathrm{~min}$ of DRM at $750{ }^{\circ} \mathrm{C}$ over the $5 \mathrm{wt} \%$ $\mathrm{Ni}$ supported on differently prepared $\mathrm{CeO}_{2}$ solids. The $\mathrm{Ni} / \mathrm{CeO}_{2}-\mathrm{HT}$ presented the highest catalytic

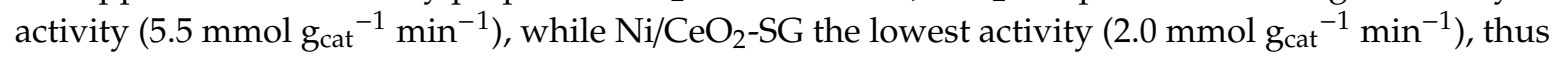
a significant difference by a factor of $\sim 2.9$ existed between these two catalysts. On the other hand, the $\mathrm{H}_{2} / \mathrm{CO}$ gas product ratio did not follow the activity differences shown in Figure 2A (compare Figure $2 \mathrm{~A}, \mathrm{~B}$ ) since the most active $\mathrm{Ni} / \mathrm{CeO}_{2}-\mathrm{HT}$ exhibited a value of $\sim 1.2$ (similar to -TD and -PT) and the least active $\mathrm{Ni} / \mathrm{CeO}_{2}-\mathrm{SG}$ presented a value of $\sim 1.1$. These results clearly demonstrated that the series of four catalysts presented different orders in terms of $\mathrm{H}_{2}$ and $\mathrm{CO}$ reaction selectivity. It should be noted that all four catalytic systems presented $\mathrm{X}_{\mathrm{CH} 4}(\%)$ and $\mathrm{X}_{\mathrm{CO} 2}(\%)$ larger than $80 \%(81-94 \%)$, with $\mathrm{H}_{2}$-yields larger than $45 \%(48-59 \%)$ and $\mathrm{H}_{2} / \mathrm{CO}$ gas product ratio close to the desired value of $\sim 1$, tested at the same GHSV $\left(30,000 \mathrm{~h}^{-1}\right)$ (see Table S2).
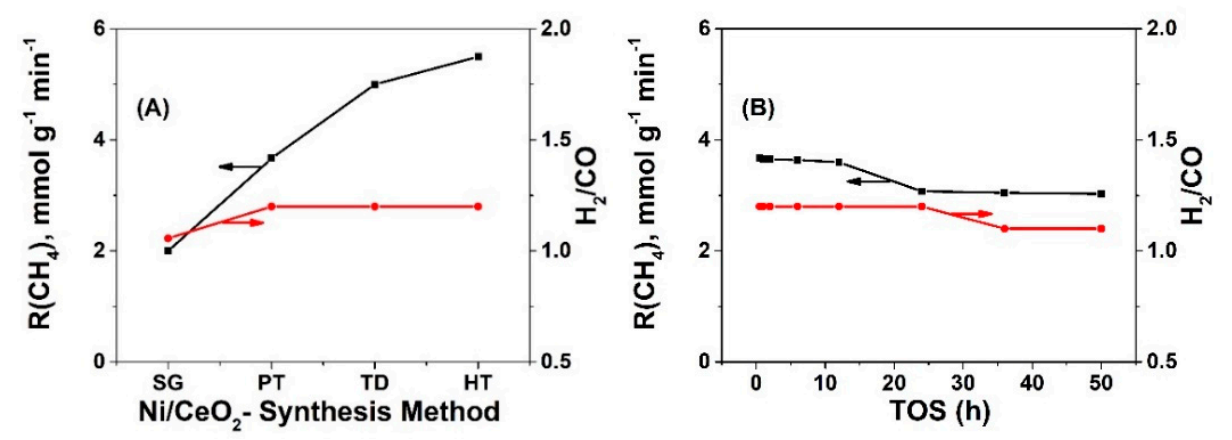

Figure 2. (A) Specific integral rates of $\mathrm{CH}_{4}$ conversion (mmol gcat ${ }^{-1} \mathrm{~min}^{-1}$ ) and $\mathrm{H}_{2} / \mathrm{CO}$ gas product ratio obtained after $30 \mathrm{~min}$ of DRM at $750{ }^{\circ} \mathrm{C}\left(\mathrm{GHSV} \sim 30,000 \mathrm{~h}^{-1}\right.$ ) over the four catalysts; (B) Stability test in terms of integral rate of $\mathrm{CH}_{4}$ conversion conducted over $50 \mathrm{~h}$ of TOS on $5 \mathrm{wt} \% \mathrm{Ni} / \mathrm{CeO}_{2}-\mathrm{PT}$ catalyst; GHSV $\sim 30,000 \mathrm{~h}^{-1}$.

Figure $2 \mathrm{~B}$ presents the stability test (up to $50 \mathrm{~h}$ on TOS) for the $5 \mathrm{wt} \% \mathrm{Ni} / \mathrm{CeO}_{2}-\mathrm{PT}$ catalyst, which exhibited the least amount of accumulated carbon $\left(\mathrm{mg} \mathrm{g}_{\mathrm{cat}}{ }^{-1}\right)$ after $12 \mathrm{~h}$ on TOS among the series of catalysts. It was clearly seen that after up to $\sim 12 \mathrm{~h}$ on TOS, the catalyst's activity remained practically 
constant, while a drop by $\sim 17.5 \%$ in the integral rate of methane conversion occurred after $50 \mathrm{~h}$ on TOS (see also Table S3). Similar results were also observed for the other three catalyst compositions (not reported). The comparative activity behavior based on 30-min on TOS shown in Figure 2A is thus very representative for the true effect of ceria support synthesis method.

It's worth mentioning that regarding the $\mathrm{CO}_{2}$ conversion (\%), this was found to be lower than that of $\mathrm{CH}_{4}$ for all catalytic systems except in the case of $\mathrm{Ni} / \mathrm{CeO}_{2}-\mathrm{SG}$. The latter result was similar to that obtained over other $\mathrm{CeO}_{2}$-supported $\mathrm{Ni}$ catalysts [17,50], and is mainly attributed to the effect of reverse water-gas shift (RWGS) side reaction. It will be shown in the following Section 2.6, that the four catalysts, for their activity performance depicted in Figure 2A, also exhibited significantly different amounts of carbon accumulation due to their different $\mathrm{CeO}_{2}$ support preparation method.

\subsection{Characterization of Carbon Formed under Different Reaction Conditions}

\subsubsection{Dry Reforming of Methane $\left({ }^{12} \mathrm{CO}_{2} /{ }^{12} \mathrm{CH}_{4}\right)$ at Steady-State Reaction Conditions}

Transient response curves of $\mathrm{CO}_{2}$ obtained during temperature-programmed oxidation (TPO) of carbon deposited over the four $\mathrm{Ni} / \mathrm{CeO}_{2}$ catalysts after $12 \mathrm{~h}$ in DRM $\left(20 \mathrm{vol} \% \mathrm{CH}_{4} / 20 \mathrm{vol} \% \mathrm{CO}_{2} / 60\right.$ vol\% $\mathrm{He}$ ) at $750{ }^{\circ} \mathrm{C}$ are presented in Figure $3 \mathrm{~A}$. The $\mathrm{Ni} / \mathrm{CeO}_{2}-\mathrm{PT}$ led to a lower carbon accumulation, ca. 3.8 times (30.7 vs. $116.1 \mathrm{mg} \mathrm{C} \mathrm{g}_{\text {cat }}{ }^{-1}$ ) compared to the $\mathrm{Ni} / \mathrm{CeO}_{2}-\mathrm{HT}$ catalyst, with the other two catalysts, $\mathrm{Ni} / \mathrm{CeO}_{2}-\mathrm{TD}$ and $\mathrm{Ni} / \mathrm{CeO}_{2}-\mathrm{SG}$ showing a decrease by 1.8 and 1.4 times $(66.2$ and $80.4 \mathrm{mg}$ $\mathrm{C} \mathrm{g}_{\text {cat }}{ }^{-1}$ ), respectively. In the case of $\mathrm{Ni} / \mathrm{CeO}_{2}-\mathrm{TD}$ and $\mathrm{Ni} / \mathrm{CeO}_{2}-\mathrm{PT}$ catalysts, a main peak starting at $450{ }^{\circ} \mathrm{C}$ and ending at $750{ }^{\circ} \mathrm{C}$ with peak maximum at $\sim 630^{\circ} \mathrm{C}$ was observed, whereas in the case of $\mathrm{Ni} / \mathrm{CeO}_{2}-\mathrm{HT}$, a wider main peak was observed, which was centered at $\sim 670{ }^{\circ} \mathrm{C}$. As opposed to the latter behavior, the $\mathrm{Ni} / \mathrm{CeO}_{2}-\mathrm{SG}$ (Figure $3 \mathrm{Ad}$ ) presented likely several types of carbon, since it started reacting with oxygen at $\sim 500{ }^{\circ} \mathrm{C}$ with a shoulder at $600{ }^{\circ} \mathrm{C}$ and a main peak at $700{ }^{\circ} \mathrm{C}$, but a clear sharp peak at $750{ }^{\circ} \mathrm{C}$ was also observed; the latter might have also been the result of a hot spot in the catalytic bed formed at these high temperatures given the large exotherm of carbon oxidation to $\mathrm{CO}_{2}$.
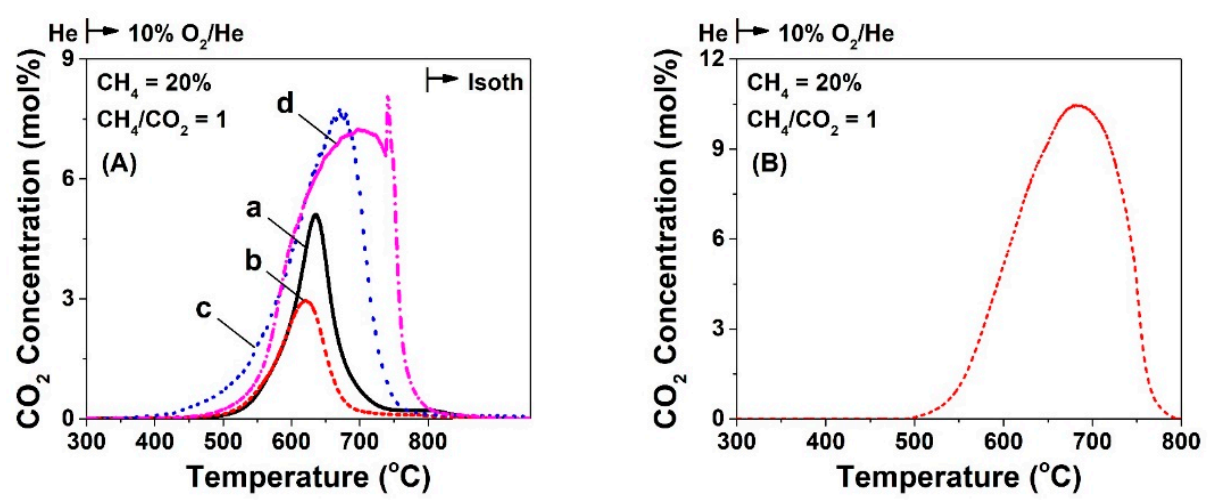

Figure 3. Transient response curves of $\mathrm{CO}_{2}$ concentration obtained during TPO of carbon formed

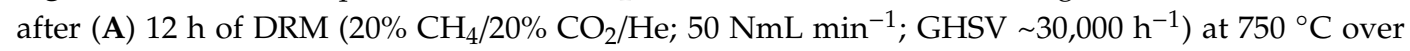
$5 \mathrm{wt} \% \mathrm{Ni} / \mathrm{CeO}_{2}$ prepared by (a) Thermal decomposition (TD), (b) Precipitation (PT), (c) Hydrothermal (HT), and (d) Sol-Gel (SG) method; (B) TPO trace of carbon formed after $50 \mathrm{~h}$ in DRM over the $5 \mathrm{wt} \%$ $\mathrm{Ni} / \mathrm{CeO}_{2}$-PT catalyst.

The $\mathrm{Ni} / \mathrm{CeO}_{2}-\mathrm{PT}$ catalyst, which led to the lowest amount of carbon deposition, was also tested for longer time-on-stream (ca. $50 \mathrm{~h}$, see Figure 2B, Table S3), and the TPO trace recorded is presented in Figure 3B. The amount of carbon deposition was increased when the TOS increased from $12 \mathrm{~h}$ to $50 \mathrm{~h}$, ca. 147.1 vs. $30.7 \mathrm{mg} \mathrm{C} \mathrm{g}^{-1}$ cat (see also Table S3). These results will be discussed below in relation to a synergy observed for carbon accumulation between $\mathrm{CH}_{4}$ and $\mathrm{CO}$ presence in the same gas mixture compared to the $\mathrm{CH}_{4}$ decomposition and Boudouard reaction contribution alone. 


\subsubsection{Isotopically Labelled Dry Reforming of Methane $\left({ }^{13} \mathrm{CO}_{2} /{ }^{12} \mathrm{CH}_{4}\right)$}

Figure 4 presents ${ }^{13} \mathrm{CO}_{2}$ and ${ }^{12} \mathrm{CO}_{2}$ transient response curves recorded during TPO of the carbon formed after $30 \mathrm{~min}$ in isotopically labelled DRM (5 vol $\left.\%{ }^{13} \mathrm{CO}_{2} / 5 \mathrm{vol} \%{ }^{12} \mathrm{CH}_{4} / 45 \mathrm{vol} \% \mathrm{Ar} / 45 \mathrm{vol} \% \mathrm{He}\right)$ at $750{ }^{\circ} \mathrm{C}$ over the $\mathrm{Ni} / \mathrm{CeO}_{2}-\mathrm{TD}, \mathrm{Ni} / \mathrm{CeO}_{2}-\mathrm{HT}$, and $\mathrm{Ni} / \mathrm{CeO}_{2}-\mathrm{SG}$ catalysts. It's worth mentioning that the $\mathrm{Ni} / \mathrm{CeO}_{2}-\mathrm{PT}$, where the support was prepared by the precipitation method $\left(\mathrm{CeO}_{2}-\mathrm{PT}\right)$, exhibited non-measurable amounts of carbon, and neither ${ }^{12} \mathrm{CO}$ nor ${ }^{13} \mathrm{CO}$ signals were recorded in the MS. The TPO traces of ${ }^{13} \mathrm{CO}_{2}$ and ${ }^{12} \mathrm{CO}_{2}$ were different in shape among the three catalytic systems, and this was largely attributed to the different carbon oxidation kinetics influenced by the type of carbon deposited, and its reactivity towards oxygen. The ${ }^{13} \mathrm{CO}_{2}$-TPO trace originated from the ${ }^{13} \mathrm{CO}_{2}$ activation route during DRM, while that of ${ }^{12} \mathrm{CO}_{2}$-TPO from the ${ }^{12} \mathrm{CH}_{4}$ activation route. Furthermore, the three catalysts presented different amounts of carbon formed via the two activation routes but also a different total amount of carbon, which was estimated by integrating the respective TPO traces. The contribution of each reactant $\left(\mathrm{CH}_{4}\right.$ vs. $\left.\mathrm{CO}_{2}\right)$ to the carbon formation under DRM reaction conditions was estimated based on the ratio of ${ }^{12} \mathrm{CO}_{2} /{ }^{13} \mathrm{CO}_{2}$ (TPO traces). It was shown that in all three catalytic systems, $\mathrm{CH}_{4}$ decomposition is the dominant route, but to a different extent. More precisely, the $\mathrm{Ni} / \mathrm{CeO}_{2}-\mathrm{TD}$ (Figure $4 \mathrm{~A}$ ) and $\mathrm{Ni} / \mathrm{CeO}_{2}-\mathrm{HT}$ (Figure $4 \mathrm{~B}$ ) presented ${ }^{12} \mathrm{C} /{ }^{13} \mathrm{C}=1.6$ and 1.8 , respectively, as opposed to the Ni/CeO ${ }_{2}-\mathrm{SG}$ catalyst (Figure $4 \mathrm{C}$ ), where $\mathrm{CH}_{4}$ decomposition contributed in a significantly higher extent $\left({ }^{12} \mathrm{C} /{ }^{13} \mathrm{C}=4.7\right)$. In addition, the total amount of carbon was found to be larger in the case of $\mathrm{Ni} / \mathrm{CeO}_{2}-\mathrm{HT}\left(29.5 \mu \mathrm{mol} \mathrm{g}^{-1}\right)$ compared to $\mathrm{Ni} / \mathrm{CeO}_{2}-\mathrm{SG}$ and $\mathrm{Ni} / \mathrm{CeO}_{2}-\mathrm{TD}\left(28.1\right.$ and $11.1 \mu \mathrm{mol} \mathrm{g}{ }^{-1}$, respectively). The latter results agree with those presented in Section 2.6.1, where the feed gas stream ( $5 \mathrm{vs} .20 \mathrm{vol} \%$ of reactants) and the TOS (30 min vs. $12 \mathrm{~h}$ ) were much different.
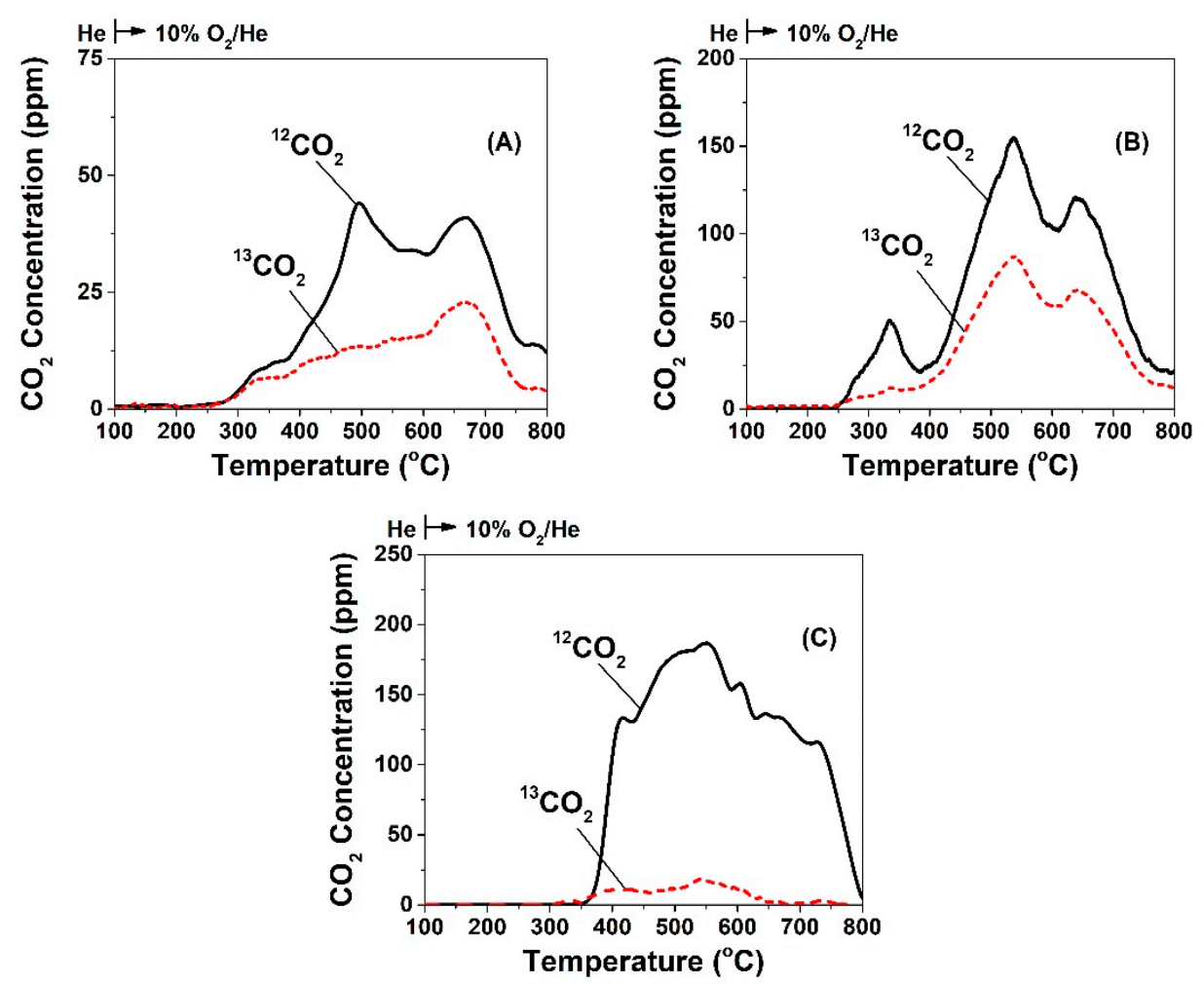

Figure 4. Temperature-programmed oxidation (TPO) of carbon to ${ }^{12} \mathrm{CO}_{2}$ and ${ }^{13} \mathrm{CO}_{2}$ formed after $30 \mathrm{~min}$ in $5 \mathrm{vol} \%{ }^{13} \mathrm{CO}_{2} / 5 \mathrm{vol} \%{ }^{12} \mathrm{CH}_{4} / 45 \mathrm{vol} \% \mathrm{Ar} / 45 \mathrm{vol} \% \mathrm{He}\left(50 \mathrm{NmL} \mathrm{min}{ }^{-1}\right.$; GHSV $\left.30,000 \mathrm{~h}^{-1}\right)$ at $750{ }^{\circ} \mathrm{C}$ over (A) $5 \mathrm{wt} \% \mathrm{Ni} / \mathrm{CeO}_{2}-\mathrm{TD}$, (B) $5 \mathrm{wt} \% \mathrm{Ni} / \mathrm{CeO}_{2}-\mathrm{HT}$, and (C) $5 \mathrm{wt} \% \mathrm{Ni} / \mathrm{CeO}_{2}-\mathrm{SG}$. 


\subsubsection{Transient Methane Decomposition $\left(\mathrm{CH}_{4} / \mathrm{He}\right)$ Reaction}

Figure 5 shows transient evolution rates of $\mathrm{CH}_{4}$ consumption and $\mathrm{H}_{2}$ and $\mathrm{CO}$ gas formation (the only gaseous reaction products observed), obtained during the step gas switch $\mathrm{He} \rightarrow 20 \mathrm{vol} \%$ $\mathrm{CH}_{4} / 1 \% \mathrm{Ar} / \mathrm{He}\left(30 \mathrm{~min}\right.$ ) made at $750{ }^{\circ} \mathrm{C}$ over the four $5 \mathrm{wt} \% \mathrm{Ni}$ supported on $\mathrm{CeO}_{2}$ carriers prepared by different synthesis methods. The differences in the initial transient rate values, but also their shapes, are apparent. It should be mentioned at this point that the latter rates appeared very small when the reaction was performed over the supports alone. The different kinetics of $\mathrm{CH}_{4}$ decomposition, over each of the four catalytic surfaces presented in Figure 5A, led also to different $\mathrm{H}_{2}$ transient formation rates (Figure 5B), similar in shape with those of $\mathrm{CH}_{4}$ consumption (Figure $5 \mathrm{~A}$ ). On the other hand, the rate of $\mathrm{CO}$ formation was the result of carbon removal by the support's lattice oxygen, which followed largely different kinetics (compare Figure 5B,C). In particular, the $\mathrm{H}_{2}$ transient rates in the case of $\mathrm{Ni} / \mathrm{CeO}_{2}-\mathrm{TD}$ and $\mathrm{Ni} / \mathrm{CeO}_{2}-\mathrm{PT}$ passed through a maximum a short time after the switch $(<10 \mathrm{~s})$, as opposed to $\mathrm{Ni} / \mathrm{CeO}_{2}-\mathrm{HT}$ and $\mathrm{Ni} / \mathrm{CeO}_{2}-\mathrm{SG}$, which passed through a maximum after $25 \mathrm{~s}$ in $\mathrm{CH}_{4} / \mathrm{Ar} / \mathrm{He}$ feed gas stream. Also, the latter catalyst presented only a slight decrease in the reaction rates after maximum rate was achieved (practically a plateau in the rate is obtained (Figure 5Ad,Bd,Cd). It has been discussed that these transient features reflect the Ni metal surface's ability to decompose methane over the remaining empty sites with time on stream, leading to carbon structure dependent deposition with different kinetics $[18,20]$.
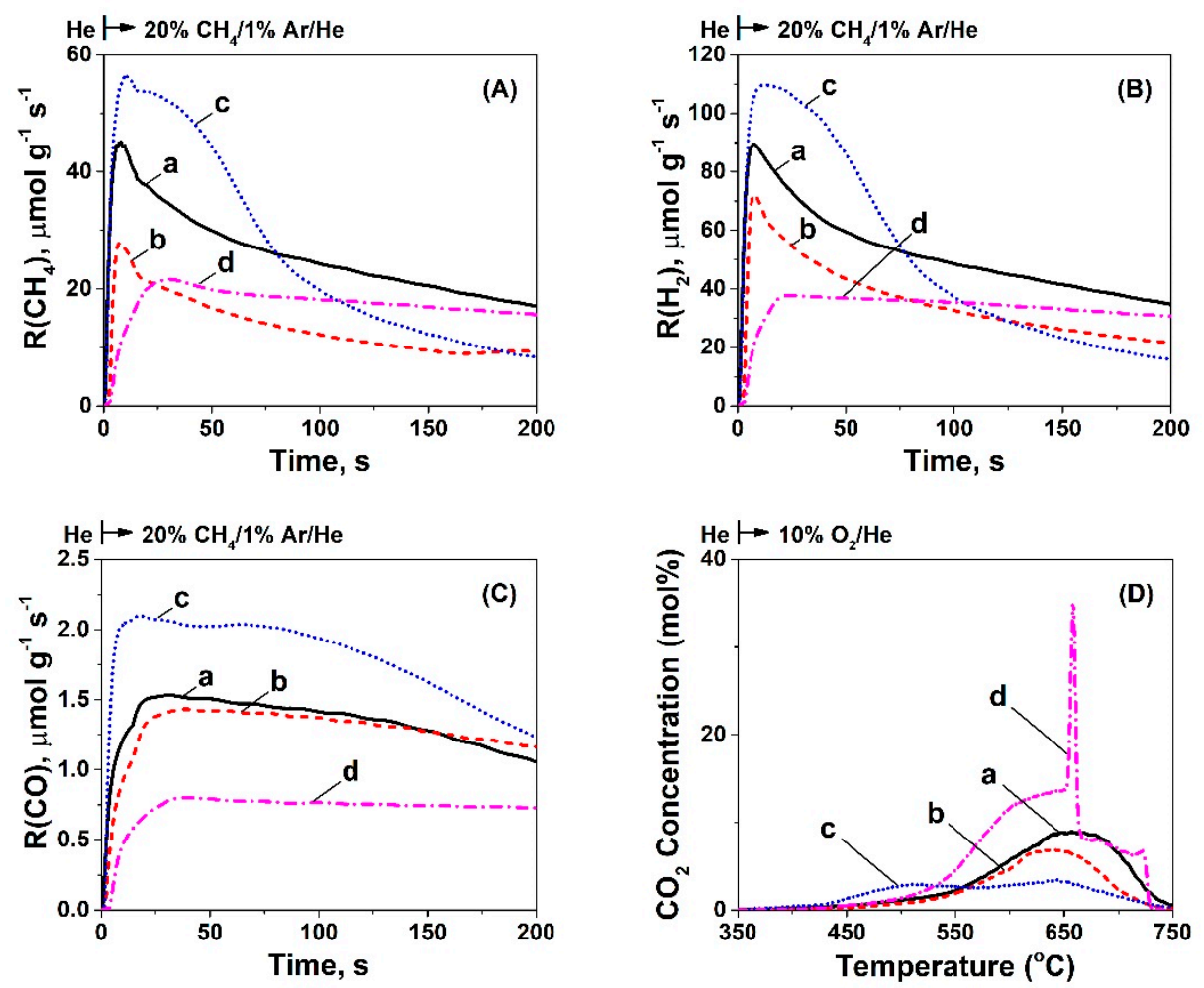

Figure 5. Transient rates $\left(\mu \mathrm{mol} \mathrm{g}{ }^{-1} \mathrm{~s}^{-1}\right.$ ) of $\mathrm{CH}_{4}$ consumption $(\mathbf{A}), \mathrm{H}_{2}(\mathbf{B})$, and $\mathrm{CO}(\mathbf{C})$ formation, as a function of time after the gas switch $\mathrm{He} \rightarrow 20 \mathrm{vol} \% \mathrm{CH}_{4} / 1 \% \mathrm{Ar} / \mathrm{He}\left(50 \mathrm{NmL} \mathrm{min}^{-1}\right.$; GHSV $30,000 \mathrm{~h}^{-1}$ ) at $750{ }^{\circ} \mathrm{C}$. (D) Transient response curves of $\mathrm{CO}_{2}$ concentration obtained during TPO of carbon formed after $30 \mathrm{~min}$ of methane decomposition $\left(20 \% \mathrm{CH}_{4} / 1 \% \mathrm{Ar} / \mathrm{He}\right)$ at $750{ }^{\circ} \mathrm{C}$ over $5 \mathrm{wt} \% \mathrm{Ni} / \mathrm{CeO}_{2}$ prepared by (a) Thermal decomposition (TD), (b) Precipitation (PT), (c) Hydrothermal (HT), and (d) Sol-Gel (SG) method.

The carbon accumulated over the ceria-supported Ni catalytic surface can diffuse towards the Ni-support interface, where it was gasified to form $\mathrm{CO}(\mathrm{g})$ by the support's labile lattice oxygen, and this chemical process was likely responsible for the delay in the peak maximum, as shown in Figure 5C. 
However, lattice oxygen diffusion towards carbon formed on $\mathrm{Ni}$ and/or Ni-ceria support interface can also be considered, as discussed in Section 3.2. The $\mathrm{H}$ - and $\mathrm{C}$-material balances close within less than $5 \%$ (Table 1). In particular, the amount of $\mathrm{CH}_{4}$ decomposed was found to be the same $\left(7.8 \mathrm{mmol} \mathrm{g}^{-1}\right)$ for $\mathrm{Ni} / \mathrm{CeO}_{2}-\mathrm{PT}$ and $\mathrm{Ni} / \mathrm{CeO}_{2}-\mathrm{HT}$, an amount which increases by about 1.3 and 1.6 times for $\mathrm{Ni} / \mathrm{CeO}_{2}-\mathrm{SG}$ and $\mathrm{Ni} / \mathrm{CeO}_{2}-\mathrm{TD}$, ca. 10 and $12.2 \mathrm{mmol} \mathrm{g}^{-1}$, respectively. On the other hand, the amount of $\mathrm{CO}$ formed was found to be $0.9 \mathrm{mmol} \mathrm{g}_{\mathrm{cat}}^{-1}$ in the cases of $\mathrm{Ni} / \mathrm{CeO}_{2}-\mathrm{PT}$ and $\mathrm{Ni} / \mathrm{CeO}_{2}-\mathrm{HT}$, but slightly lower in the case of $\mathrm{Ni} / \mathrm{CeO}_{2}-\mathrm{TD}$ and $\mathrm{Ni} / \mathrm{CeO}_{2}-\mathrm{SG}$, ca. 0.8 and $0.6 \mathrm{mmol} \mathrm{g}_{\text {cat }}{ }^{-1}$, respectively. The amount of $\mathrm{H}_{2}$ produced was lower in the case of $\mathrm{Ni} / \mathrm{CeO}_{2}-\mathrm{HT}\left(14.9 \mathrm{mmol} \mathrm{g}_{\mathrm{cat}}{ }^{-1}\right)$ compared to $\mathrm{Ni} / \mathrm{CeO}_{2}-\mathrm{PT}$ $\left(16.4 \mathrm{mmol} \mathrm{g}_{\mathrm{cat}}{ }^{-1}\right), \mathrm{Ni} / \mathrm{CeO}_{2}-\mathrm{SG}\left(22 \mathrm{mmol} \mathrm{g}_{\mathrm{cat}}{ }^{-1}\right)$, and Ni/CeO ${ }_{2}-\mathrm{TD}\left(26.4 \mathrm{mmol} \mathrm{g}_{\mathrm{cat}}{ }^{-1}\right)$. Of interest is the amount of labile oxygen of the ceria support contributing to the gasification of carbon towards $\mathrm{CO}(\mathrm{g})$, which could be quantified by estimating the ratio between the $\mathrm{CO}$ production and $\mathrm{CH}_{4}$ consumption, as shown in Table 1. This ratio was found to be the same (0.12) for the $\mathrm{Ni} / \mathrm{CeO}_{2}-\mathrm{PT}$ and $\mathrm{Ni} / \mathrm{CeO}_{2}-\mathrm{HT}$ catalysts, but significantly lower in the case of $\mathrm{Ni} / \mathrm{CeO}_{2}-\mathrm{TD}(0.07)$ and $\mathrm{Ni} / \mathrm{CeO}_{2}-\mathrm{SG}(0.06)$, showing clearly the lower contribution of $\mathrm{O}_{\mathrm{L}}$ (active labile oxygen) towards $\mathrm{CO}(\mathrm{g})$.

Table 1. Quantity of $\mathrm{CH}_{4}$ consumed, $\mathrm{H}_{2}$ and $\mathrm{CO}$ formed $\left(\mathrm{mmol} \mathrm{g}^{-1}\right)$, and molar ratio of $\mathrm{CO} / \mathrm{CH}_{4}$ obtained after $30 \mathrm{~min}$ of methane decomposition $\left(20 \% \mathrm{CH}_{4} / \mathrm{He}\right)$ conducted at $750{ }^{\circ} \mathrm{C}$. Also shown is the amount of carbon deposited $\left(\mathrm{mmol} \mathrm{g}^{-1}\right)$, which was obtained after TPO following $30 \mathrm{~min}$ of methane decomposition.

\begin{tabular}{|c|c|c|c|c|c|}
\hline $\begin{array}{c}\text { Catalyst } \\
\left(5 \mathrm{wt}^{\circ} \% \mathrm{Ni}\right)\end{array}$ & $\begin{array}{l}\mathrm{CH}_{4} \text { Consumption } \\
\left(\mathrm{mmol} \mathrm{g}^{-1}\right)\end{array}$ & $\begin{array}{c}\mathrm{H}_{2} \text { Production } \\
\left(\mathrm{mmol} \mathrm{g}^{-1}\right)\end{array}$ & $\begin{array}{l}\text { CO Production } \\
\left(\mathrm{mmol} \mathrm{g}^{-1}\right)\end{array}$ & $\mathrm{CO} / \mathrm{CH}_{4}$ & $\begin{array}{l}\text { Carbon Deposition } \\
\left(\mathrm{mmol} \mathrm{g}^{-1}\right)\end{array}$ \\
\hline $\mathrm{CeO}_{2}-\mathrm{TD}$ & 12.2 & 26.4 & 0.8 & 0.07 & 12.1 \\
\hline $\mathrm{CeO}_{2}-\mathrm{PT}$ & 7.8 & 16.4 & 0.9 & 0.12 & 8.3 \\
\hline $\mathrm{CeO}_{2}-\mathrm{HT}$ & 7.8 & 14.9 & 0.9 & 0.12 & 6.8 \\
\hline $\mathrm{CeO}_{2}$-SG & 10 & 22 & 0.6 & 0.06 & 10.7 \\
\hline
\end{tabular}

Following the 30 min $\mathrm{CH}_{4}$ decomposition performed at $750{ }^{\circ} \mathrm{C}$ over the $\mathrm{Ni} / \mathrm{CeO}_{2}$ catalysts, temperature-programmed oxidation was performed to estimate the amount of carbon and its reactivity towards oxygen. The TPO traces in terms of $\mathrm{CO}_{2}$ concentration $(\mathrm{mol} \%)$ are depicted in Figure 5D, and the amount of carbon deposited $\left(\mathrm{mmol} \mathrm{g}^{-1}\right)$ is reported in Table 1 . The latter results were in harmony with the amount of $\mathrm{CH}_{4}$ consumed and $\mathrm{H}_{2}$ produced, as reported above. However, it should be mentioned at this point that these values did not agree with the results regarding the amount of carbon deposited during DRM, where $\mathrm{Ni} / \mathrm{CeO}_{2}-\mathrm{HT}$ was found to accumulate more carbon. As it will be discussed in the following sections, we argue that the carbon formation rate, and that of carbon removal towards $\mathrm{CO}$ formation, are largely influenced when both $\mathrm{CH}_{4}$ and $\mathrm{CO}_{2}$ (or $\mathrm{CO}$ ) are present over the ceria-supported $\mathrm{Ni}$ catalyst surface to be compared to the case when $\mathrm{CH}_{4}, \mathrm{CO}_{2}$, or $\mathrm{CO}$ is only present.

\subsubsection{Transient Carbon Monoxide Dissociation (CO/He) Reaction}

The transient rates of $\mathrm{CO}(\mathrm{g})$ consumption obtained during the step-gas switch $\mathrm{He} \rightarrow 20 \mathrm{vol} \%$ $\mathrm{CO} / 1 \mathrm{vol} \% \mathrm{Ar} / \mathrm{He}\left(750^{\circ} \mathrm{C}, 30 \mathrm{~min}\right)$ over the four catalysts are presented in Figure $6 \mathrm{~A}$. It was clearly shown that during the reverse Boudouard reaction, two peak maxima were present, as opposed to the case of $\mathrm{CH}_{4}$ decomposition reaction (Figure $5 \mathrm{~A}$ ). The first very sharp peak was formed immediately $\left(t_{\max } \sim 5 \mathrm{~s}\right)$ after the switch from inert $\mathrm{He}$ to $\mathrm{CO} / \mathrm{Ar} / \mathrm{He}$, followed by a fast decay, while the second peak appeared at $t_{\max } \sim 20 \mathrm{~s}$ and was followed by a slower rate of $\mathrm{CO}$ consumption. Thus, the kinetics involved in both the initial very sharp and the slower transient rates of carbon monoxide dissociation are strongly affected by differences in the four catalytic surfaces. 

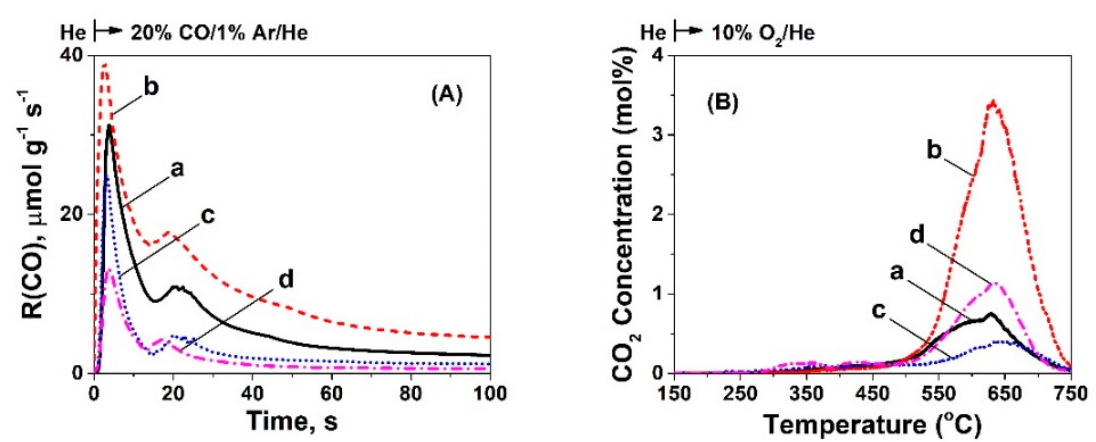

Figure 6. Transient rates $\left(\mu \mathrm{mol} \mathrm{g}{ }^{-1} \mathrm{~s}^{-1}\right)$ of (A) CO consumption as a function of time after the gas switch $\mathrm{He} \rightarrow 20 \mathrm{vol} \% \mathrm{CO} / 1 \mathrm{vol} \% \mathrm{Ar} / \mathrm{He}\left(50 \mathrm{NmL} \mathrm{m^{-1 }}{ }^{-}\right.$GHSV $\left.\sim 30,000 \mathrm{~h}^{-1}\right)$ at $750{ }^{\circ} \mathrm{C}$. (B) Transient response curves of $\mathrm{CO}_{2}$ concentration obtained during TPO of carbon formed after $30 \mathrm{~min}$ of $\mathrm{CO}$ dissociation at $750{ }^{\circ} \mathrm{C}$ over $5 \mathrm{wt} \% \mathrm{Ni} / \mathrm{CeO}_{2}$ prepared by (a) Thermal decomposition (TD), (b) Precipitation (PT), (c) Hydrothermal (HT), and (d) Sol-Gel (SG) method.

Figure $6 \mathrm{~B}$ presents the TPO traces obtained after the reaction with $20 \mathrm{vol} \% \mathrm{CO} / 1 \mathrm{vol} \% \mathrm{Ar} / \mathrm{He}$ (30 min) at $750{ }^{\circ} \mathrm{C}$. The four catalytic surfaces showed one main peak centered at $\sim 600^{\circ} \mathrm{C}$ with shoulders, revealing likely the existence of different carbon structures, oxidized with different kinetics. Table 2 presents the amount of carbon deposited during the $30 \mathrm{~min}$ reaction with $\mathrm{CO} / \mathrm{Ar} / \mathrm{He}$. The largest amount of carbon deposited was found to be on the $\mathrm{Ni} / \mathrm{CeO}_{2}-\mathrm{PT}\left(2.7 \mathrm{mmol} \mathrm{g}^{-1}\right)$ followed by the $\mathrm{Ni} / \mathrm{CeO}_{2}-\mathrm{TD}\left(1.1 \mathrm{mmol} \mathrm{g}^{-1}\right), \mathrm{Ni} / \mathrm{CeO}_{2}-\mathrm{HT}\left(0.8 \mathrm{mmol} \mathrm{g}^{-1}\right)$, and $\mathrm{Ni} / \mathrm{CeO}_{2}-\mathrm{SG}\left(0.6 \mathrm{mmol} \mathrm{g}^{-1}\right)$ catalysts. The C-material balance closes within less than $5 \%$ in all cases (Table 2).

Table 2. Quantity of $\mathrm{CO}$ consumption and $\mathrm{CO}_{2}$ formation $\left(\mathrm{mmol} \mathrm{g}^{-1}\right)$ obtained after $30 \mathrm{~min} 20 \% \mathrm{CO} / \mathrm{He}$ at $750{ }^{\circ} \mathrm{C}$. Also shown is the amount of carbon deposition $\left(\mathrm{mmol} \mathrm{g}^{-1}\right)$ obtained after TPO following 30 min of $\mathrm{CO}$ disproportionation.

\begin{tabular}{|c|c|c|c|}
\hline $\begin{array}{c}\text { Catalyst } \\
(5 \mathrm{wt} \% \mathrm{Ni})\end{array}$ & $\begin{array}{l}\text { CO Consumption } \\
\left(\mathrm{mmol} \mathrm{g}^{-1}\right)\end{array}$ & $\begin{array}{l}\mathrm{CO}_{2} \text { Production } \\
\left(\mathrm{mmol} \mathrm{g}^{-1}\right)\end{array}$ & $\begin{array}{l}\text { Carbon Deposition } \\
\quad\left(\mathrm{mmol} \mathrm{g}^{-1}\right)\end{array}$ \\
\hline $\mathrm{CeO}_{2}-\mathrm{TD}$ & 1.9 & 1.0 & 1.2 \\
\hline $\mathrm{CeO}_{2}-\mathrm{PT}$ & 4.9 & 2.2 & 2.7 \\
\hline $\mathrm{CeO}_{2}-\mathrm{HT}$ & 1.7 & 0.8 & 0.8 \\
\hline $\mathrm{CeO}_{2}$ - SG & 1.1 & - & 0.6 \\
\hline
\end{tabular}

\subsubsection{Isotopically Labelled Competitive $\left({ }^{13} \mathrm{CO} /{ }^{12} \mathrm{CH}_{4}\right)$ Reaction towards Carbon Formation}

Figure 7 presents $\mathrm{CO}(\mathrm{C}, \mathrm{D})$ and $\mathrm{CO}_{2}(\mathrm{~A}, \mathrm{~B})$ concentration $(\mathrm{mol} \%)$ profiles obtained after temperature-programmed oxidation (TPO) following a 20-min treatment of the $\mathrm{Ni} / \mathrm{CeO}_{2}-\mathrm{TD}$ (a), $\mathrm{Ni} / \mathrm{CeO}_{2}-\mathrm{PT}(\mathrm{b}), \mathrm{Ni} / \mathrm{CeO}_{2}-\mathrm{HT}(\mathrm{c})$, and $\mathrm{Ni} / \mathrm{CeO}_{2}$-SG (d) catalysts with $2.5 \mathrm{vol} \%{ }^{12} \mathrm{CH}_{4} / 2.5 \mathrm{vol} \%{ }^{13} \mathrm{CO} / 2$ vol $\% \mathrm{Kr} / \mathrm{Ar} / \mathrm{He}$ gas mixture at $750{ }^{\circ} \mathrm{C}$. The amount of deposited carbon, but also its reactivity towards oxygen (shape and position of TPO trace), were clearly different among the four catalysts. It was shown that all catalytic systems exhibited differences in the shape of ${ }^{12} \mathrm{CO}_{2} /{ }^{12} \mathrm{CO}$ and ${ }^{13} \mathrm{CO}_{2} /{ }^{13} \mathrm{CO}$ response curves as the result of the oxidation of carbon originated from the ${ }^{12} \mathrm{CH}_{4}$ decomposition and ${ }^{13} \mathrm{CO}$ dissociation routes, respectively. Moreover, the amount of carbon derived from each route is different (area under the TPO trace), and the contribution of each route to the formation of carbon is estimated by considering the ${ }^{12} \mathrm{C} /{ }^{13} \mathrm{C}$ ratio. It is illustrated that in all cases, except $\mathrm{Ni} / \mathrm{CeO}_{2}-\mathrm{TD}(0.97)$, $\mathrm{CH}_{4}$ decomposition was dominant but to a different extent. In particular, $\mathrm{Ni} / \mathrm{CeO}_{2}-\mathrm{PT}$ showed a ratio of ${ }^{12} \mathrm{C} /{ }^{13} \mathrm{C}=1.06, \mathrm{Ni} / \mathrm{CeO}_{2}-\mathrm{HT}{ }^{12} \mathrm{C} /{ }^{13} \mathrm{C}=1.61$, and the $\mathrm{Ni} / \mathrm{CeO}_{2}-\mathrm{SG}$ a ratio of ${ }^{12} \mathrm{C} /{ }^{13} \mathrm{C}=1.5$ (Table 3). 

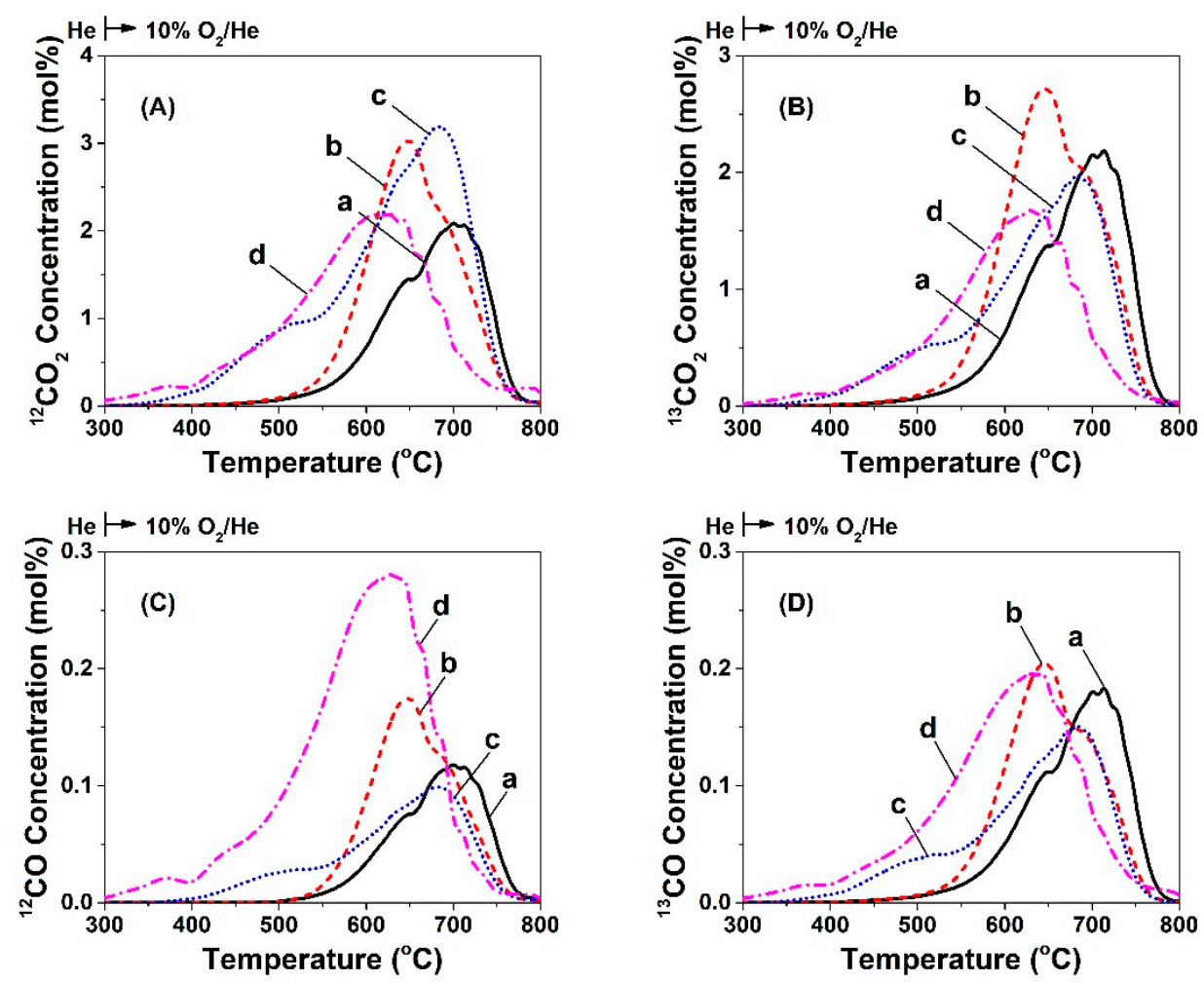

Figure 7. Temperature-programmed oxidation (TPO) of carbon to ${ }^{12} \mathrm{C}$ - and ${ }^{13} \mathrm{C}$-containing $\mathrm{CO}_{2}(\mathbf{A}, \mathbf{B})$ and $\mathrm{CO}(\mathbf{C}, \mathbf{D})$ formed after $20 \mathrm{~min}$ in $2.5 \mathrm{vol} \%{ }^{13} \mathrm{CO} / 2.5 \mathrm{vol} \%{ }^{12} \mathrm{CH}_{4} / 2 \mathrm{vol} \% \mathrm{Kr} / \mathrm{Ar} / \mathrm{He}\left(50 \mathrm{NmL} \mathrm{min}{ }^{-1}\right.$; GHSV $\sim 30,000 \mathrm{~h}^{-1}$ ) at $750{ }^{\circ} \mathrm{C}$ over $5 \mathrm{wt} \% \mathrm{Ni} / \mathrm{CeO}_{2}$ prepared by (a) Thermal decomposition (TD), (b) Precipitation (PT), (c) Hydrothermal (HT), and (d) Sol-gel (SG) method.

Table 3. Quantity of ${ }^{12} \mathrm{CO},{ }^{13} \mathrm{CO},{ }^{12} \mathrm{CO}_{2}$, and ${ }^{13} \mathrm{CO}_{2}\left(\mathrm{mmol} \mathrm{g}^{-1}\right)$ formed during TPO following $20 \mathrm{~min}$ of reaction with $2.5 \mathrm{vol} \%{ }^{13} \mathrm{CO} / 2.5 \mathrm{vol} \%{ }^{12} \mathrm{CH}_{4} / 2 \mathrm{vol} \% \mathrm{Kr} / \mathrm{Ar} / \mathrm{He}$ at $750{ }^{\circ} \mathrm{C}$ over all the $\mathrm{Ni} / \mathrm{CeO}_{2}$ catalysts. Also shown is the total amount of "carbon" $\left(\mathrm{mmol} \mathrm{g}^{-1}\right)$, and the ratio ${ }^{12} \mathrm{C}$ to ${ }^{13} \mathrm{C}$ in the products.

\begin{tabular}{|c|c|c|c|c|c|c|}
\hline $\begin{array}{c}\text { Catalyst } \\
5 \mathrm{wt} \% \\
\mathrm{Ni} / \mathrm{CeO}_{2}\end{array}$ & $\begin{array}{c}{ }^{12} \mathrm{CO} \\
\text { Production } \\
\left(\mathrm{mmol} \mathrm{g}^{-1}\right)\end{array}$ & $\begin{array}{c}{ }^{13} \mathrm{CO} \\
\text { Production } \\
\left(\mathrm{mmol} \mathrm{g}^{-1}\right)\end{array}$ & $\begin{array}{c}{ }^{12} \mathrm{CO}_{2} \\
\text { Production } \\
\left(\mathrm{mmol} \mathrm{g}^{-1}\right)\end{array}$ & $\begin{array}{c}{ }^{13} \mathrm{CO}_{2} \\
\text { Production } \\
\left(\mathrm{mmol} \mathrm{g}^{-1}\right)\end{array}$ & ${ }^{12} \mathrm{C} /{ }^{13} \mathrm{C}$ & $\begin{array}{c}\text { Carbon } \\
\text { Deposition } \\
\left(\mathrm{mmol} \mathrm{g}^{-1}\right)\end{array}$ \\
\hline $\mathrm{CeO}_{2}-\mathrm{TD}$ & 0.14 & 0.23 & 2.6 & 2.6 & 0.97 & 5.6 \\
\hline $\mathrm{CeO}_{2}-\mathrm{PT}$ & 0.14 & 0.18 & 2.6 & 2.4 & 1.06 & 5.3 \\
\hline $\mathrm{CeO}_{2}-\mathrm{HT}$ & 0.16 & 0.23 & 5.2 & 3.1 & 1.61 & 8.7 \\
\hline $\mathrm{CeO}_{2}-\mathrm{SG}$ & 0.39 & 0.25 & 3.5 & 2.4 & 1.50 & 6.5 \\
\hline
\end{tabular}

In addition, the largest amount of carbon was deposited over the $\mathrm{Ni} / \mathrm{CeO}_{2}-\mathrm{HT}$ catalyst, ca. 1.6, 1.5 , and 1.3 times higher compared to $\mathrm{Ni} / \mathrm{CeO}_{2}-\mathrm{PT}, \mathrm{Ni} / \mathrm{CeO}_{2}-\mathrm{TD}$, and $\mathrm{Ni} / \mathrm{CeO}_{2}-\mathrm{SG}(8.7$ vs. 5.3, 5.6, and $6.5 \mathrm{mmol} \mathrm{g}^{-1}$, respectively). Furthermore, multiple peaks/shoulders appeared in the TPO traces, showing that at least two kinds of carbon were formed after $\mathrm{CH}_{4} / \mathrm{CO}$ gas treatment of the four catalysts, but to a different extent. More precisely, the $\mathrm{Ni} / \mathrm{CeO}_{2}-\mathrm{HT}$ (c) and $\mathrm{Ni} / \mathrm{CeO}_{2}-\mathrm{SG}$ (d), which revealed the highest amount of carbon deposition during DRM and $\mathrm{CH}_{4} / \mathrm{CO}$ gas treatments, reveal reaction of carbon with oxygen in the range $300-800{ }^{\circ} \mathrm{C}$ as opposed to $\mathrm{Ni} / \mathrm{CeO}_{2}-\mathrm{TD}$ (a) and Ni/CeO $2-\mathrm{PT}(\mathrm{b})$, where carbon oxidation occurs in the $500-800^{\circ} \mathrm{C}$ range (more strongly bound carbon species but of lower amount). The latter results are in harmony with the results obtained under DRM reaction conditions (see Sections 2.6.1 and 2.6.2), and these will be discussed next in relation to the competitive contribution of $\mathrm{CH}_{4}$ decomposition and $\mathrm{CO}$ dissociation towards carbon formation and removal rates. 


\subsection{Participation of Support's Lattice Oxygen under DRM Conditions}

Figure $8 \mathrm{~A}$ shows the transient evolution rate of ${ }^{18} \mathrm{O}_{2}$ consumption estimated upon the $10 \mathrm{~min}$ isotopic exchange of the ${ }^{16} \mathrm{O}$ ceria lattice oxygen (surface and bulk) with gaseous ${ }^{18} \mathrm{O}_{2}$, and that due mainly to the oxidation of $\mathrm{Ni}$ to $\mathrm{Ni}^{18} \mathrm{O}$ (less to the exchange of ${ }^{16} \mathrm{O}$ with ${ }^{18} \mathrm{O}_{2}$ in $\mathrm{Ni}^{16} \mathrm{O}_{\mathrm{x}}$, see Section 4.5) at the step-gas switch $\mathrm{Ar} \rightarrow 2 \mathrm{vol} \%{ }^{18} \mathrm{O}_{2} / 2 \mathrm{vol} \% \mathrm{Kr} / \mathrm{Ar}$ at $750{ }^{\circ} \mathrm{C}$. It is seen that the ceria-supported $\mathrm{Ni}$ catalysts show similar ${ }^{18} \mathrm{O}_{2}$ consumption rates during the 10 min exchange, except the $\mathrm{Ni} / \mathrm{CeO}_{2}-\mathrm{PT}$, but all four catalysts showed a similar exchangeable amount of ${ }^{16} \mathrm{O}$ which was found to be between 10.2-12.4 mmol O g ${ }^{-1}$ (within less than $20 \%$ ), as shown in Table S6. It should be noted that the maximum amount of ${ }^{18} \mathrm{O}$ consumed, and which is related to Ni oxidation, was $0.85 \mathrm{mmol} \mathrm{g}^{-1}$. The latter illustrates that both the initial rates of ${ }^{16} \mathrm{O} /{ }^{18} \mathrm{O}$ exchanged, but also the surface and bulk mobility of ${ }^{16} \mathrm{O}$ species that were exchanged with ${ }^{18} \mathrm{O}_{2}$ were influenced by the $\mathrm{CeO}_{2}$ synthesis method and $\mathrm{Ni}$ particles size only, to a small extent.
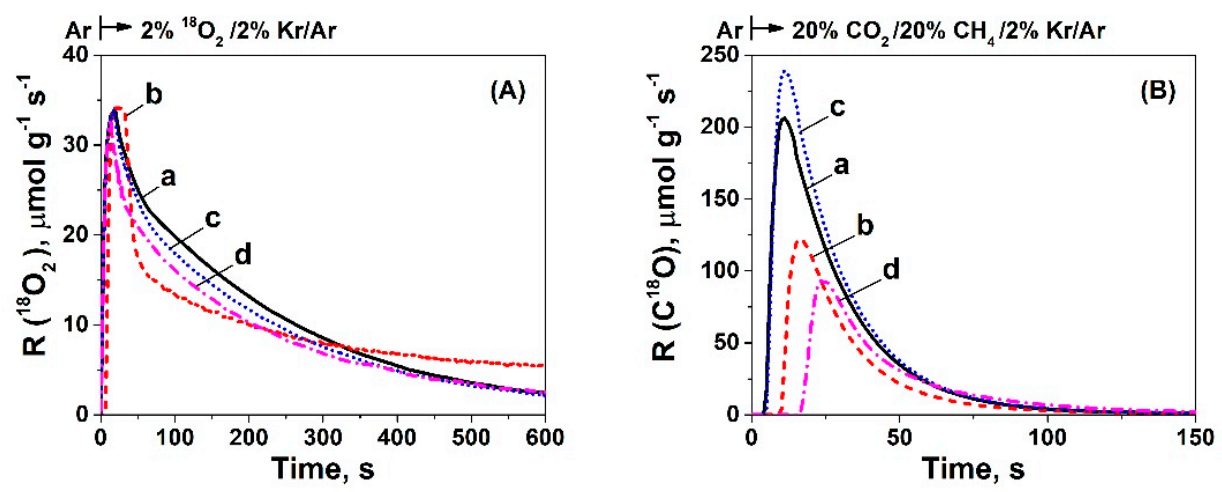

Figure 8. Transient rates ( $\mu \mathrm{mol} \mathrm{g}{ }^{-1} \mathrm{~s}^{-1}$ ) of $(\mathrm{A}){ }^{18} \mathrm{O}_{2}$ consumption during ${ }^{16} \mathrm{O} /{ }^{18} \mathrm{O}$ exchange at $750{ }^{\circ} \mathrm{C}$ after the gas switch: $\mathrm{Ar} \rightarrow 2 \%{ }^{18} \mathrm{O}_{2} / 2 \% \mathrm{Kr} / \mathrm{Ar}$, (B) $\mathrm{C}^{18} \mathrm{O}$ formation obtained during the switch from $\mathrm{Ar}$ $\rightarrow 20 \% \mathrm{CH}_{4} / 20 \% \mathrm{CO}_{2} / 2 \% \mathrm{Kr} / \mathrm{Ar} / \mathrm{He}(\mathrm{t})$ over $5 \mathrm{wt} \% \mathrm{Ni} / \mathrm{CeO}_{2}$ prepared by (a) Thermal decomposition (TD), (b) Precipitation (PT), (c) Hydrothermal (HT), and (d) Sol-Gel (SG) method. $W_{\text {cat }}=0.02$ g.

Figure $8 \mathrm{~B}$ presents the transient rates of $\mathrm{C}^{18} \mathrm{O}(\mathrm{g})$ formation over the four ceria-supported $\mathrm{Ni}$ catalysts obtained during the step-gas switch $\mathrm{Ar} \rightarrow 20 \mathrm{vol} \% \mathrm{CH}_{4} / 20 \mathrm{vol} \% \mathrm{CO}_{2} / 2 \mathrm{vol} \% \mathrm{Kr} / \mathrm{Ar}$ at $750{ }^{\circ} \mathrm{C}$, following the $10 \mathrm{~min}{ }^{16} \mathrm{O} /{ }^{18} \mathrm{O}$ exchange (Figure $8 \mathrm{~A}$ ). It was observed that all four catalysts present similar shapes of the transient rate of $\mathrm{C}^{18} \mathrm{O}(\mathrm{g})$ formation, however, they differ on their time delays and quantity (area under the transient curve). In particular, the $\mathrm{Ni} / \mathrm{CeO}_{2}-\mathrm{TD}$ and $\mathrm{Ni} / \mathrm{CeO}_{2}-\mathrm{HT}$ exhibit similar time delays $(\sim 5 \mathrm{~s})$, followed by the $\mathrm{Ni} / \mathrm{CeO}_{2}-\mathrm{PT}(\sim 10 \mathrm{~s})$ and $\mathrm{Ni} / \mathrm{CeO}_{2}-\mathrm{SG}(\sim 15 \mathrm{~s})$. In addition, the amount of $\mathrm{C}^{18} \mathrm{O}(\mathrm{g})$ produced over the four catalysts, after subtracting the equivalent amount of ${ }^{18} \mathrm{O}$ stored in the Ni during the ${ }^{18} \mathrm{O}_{2}$ gas treatment $\left(0.85 \mathrm{mmol} \mathrm{g}{ }^{-1}\right)$, was found to be 1.05 times larger for $\mathrm{Ni} / \mathrm{CeO}_{2}-\mathrm{HT}\left(6.5 \mathrm{mmol} \mathrm{g}^{-1}\right)$ compared to $\mathrm{Ni} / \mathrm{CeO}_{2}-\mathrm{TD}\left(5.9 \mathrm{mmol} \mathrm{g}^{-1}\right), 1.85$ times larger compared to $\mathrm{Ni} / \mathrm{CeO}_{2}-\mathrm{PT}\left(3.5 \mathrm{mmol} \mathrm{g}^{-1}\right)$, and 1.96 times larger compared to $\mathrm{Ni} / \mathrm{CeO}_{2}-\mathrm{SG}\left(3.3 \mathrm{mmol} \mathrm{g}^{-1}\right)$. Considering the ratio of equivalent ${ }^{18} \mathrm{O}$ in $\mathrm{C}^{18} \mathrm{O}$ (Figure 8B) to ${ }^{18} \mathrm{O}$ exchanged (Figure 8A) as the contribution of the available amount of ${ }^{18} \mathrm{O}$ to the carbon gasification, the highest value was found to result from the Ni/CeO $2-\mathrm{HT}(0.57)$, followed by Ni/CeO $2-\mathrm{TD}(0.48), \mathrm{Ni} / \mathrm{CeO}_{2}-\mathrm{SG}(0.32)$, and Ni/CeO $2-\mathrm{PT}$ (0.31). The latter results (shown also in Table S6) will be discussed in the next section regarding the importance of participation of support's lattice oxygen to the carbon gasification rate.

\section{Discussion}

\subsection{Structural Properties and Catalytic Performance of Ni Supported on $\mathrm{CeO}_{2}$ Solids}

The $5 \mathrm{wt} \% \mathrm{Ni}$ supported on $\mathrm{CeO}_{2}$ carriers prepared by different preparation methods exhibited largely different catalytic activity under DRM (20 vol $\left.\% \mathrm{CO}_{2} / 20 \mathrm{vol} \% \mathrm{CH}_{4} / \mathrm{He}, 750{ }^{\circ} \mathrm{C}\right)$ (Figure 2 ) and structural and morphological differences were apparent among them. The high conversions achieved 
in our work, are close to the calculated equilibrium values for the used feed gas composition at $1 \mathrm{~atm}$ total pressure [52]. The $5 \mathrm{wt} \% \mathrm{Ni} / \mathrm{CeO}_{2}-\mathrm{HT}$ catalyst with the largest surface area $\left(\sim 50 \mathrm{~m}^{2} \mathrm{~g}^{-1}\right)$ consisted of smaller ceria mean primary crystallite size $(\sim 11.5 \mathrm{~nm})$, smaller Ni mean particle size $(\sim 8.4 \mathrm{~nm})$, and $11.5 \% \mathrm{Ni}$ dispersion (Table S1, Figure 9$)$. On the other hand, the $5 \mathrm{wt} \% \mathrm{Ni} / \mathrm{CeO}_{2}-\mathrm{SG}$ with smaller surface area $\left(\sim 14.5 \mathrm{~m}^{2} \mathrm{~g}^{-1}\right)$, consisted of larger ceria primary crystallite size $(\sim 43.1 \mathrm{~nm})$ and $\mathrm{Ni}$ mean particle size ( $20.8 \mathrm{~nm}$; Ni dispersion $4.7 \%)$. The latter results are in good agreement with the literature $[17,19,20,44,46,53-56]$. The structural heterogeneity of the $\mathrm{CeO}_{2}$ surface had strong effect on the deposition of $\mathrm{Ni}$ species. In fact, it was reported [45] that $\mathrm{NiO}(10 \mathrm{wt} \%)$ deposited on ceria nanoparticles of cubic shape was homogeneously dispersed. Yahi et al. [43] used three different preparation methods (microemulsion, sol-gel, and autocombustion) to synthesize $\mathrm{CeO}_{2}$, on which $15 \mathrm{wt} \%$ of Ni was deposited. They clearly showed, via XRD and TPR studies, that NiO could be present with good crystallization in different phases (i.e., monoclinic and cubic phase for the auto-combustion and sol-gel, and cubic only phase for the microemulsion), which depended on the different preparation method of the ceria support. The authors [43] also reported different pore volume, surface area, and particle size by changing the preparation method, results of which are in good agreement with the present work. $\mathrm{Xu}$ et al. [55] prepared three $\mathrm{Ni} / \mathrm{Al}_{2} \mathrm{O}_{3}$ catalytic systems of the same nominal composition by varying the preparation method, namely: Impregnation, water-in-oil-microemulsion, and sol-gel. By using XRD, TEM, and TPR, they showed crystalline structural differences, both for the support and $\mathrm{Ni}$, which led to similar catalytic performance, but differences in the coking resistant, and thus in catalyst stability, as seen also in the present work. They argued that the latter differences might be due to strong metal-support interactions leading to differences on $\mathrm{Ni}$ particles size and dispersion. The latter results are in good agreement with those reported by other research groups [44,45,57], where a non-conventional synthesis method, namely the precipitation ionic exchange, led to cubic phases of $\mathrm{CeO}_{2}$ and $\mathrm{NiO}$ (verified via FEG-SEM and XRD). In a recent study, Lykaki et al. [28] showed that the hydrothermal method (among other research works which are well reported there-in) led to well defined ceria nanorods of high specific surface area and with improved redox properties.

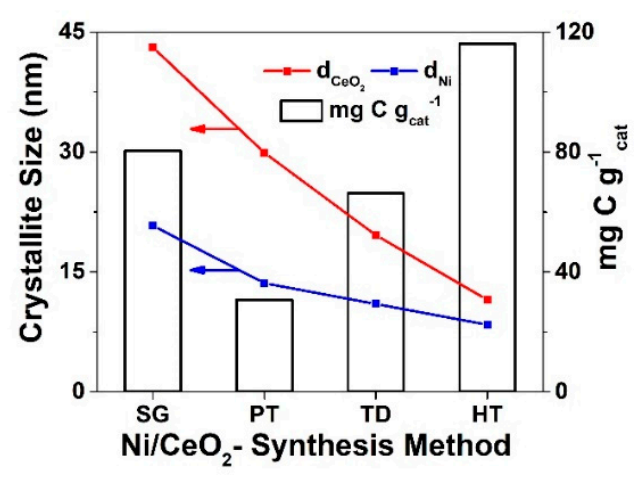

Figure 9. Comparative graph of the crystallite size $\left(\mathrm{d}_{\mathrm{CeO} 2}\right.$ and $\left.\mathrm{d}_{\mathrm{Ni}}, \mathrm{nm}\right)$ and amount of carbon deposition ( $\mathrm{mg} \mathrm{C}^{-1}$ ) after $12 \mathrm{~h}$ in DRM as a function of ceria support synthesis method.

The $\mathrm{H}_{2}$-TPD traces (Figure 1) obtained over the four catalytic systems suggest large differences in the electronic structure of the Ni supported metal surfaces (distribution of binding strength between $\mathrm{H}$ and surface $\mathrm{Ni}$ atoms $\left(\mathrm{E}_{\mathrm{Ni}-\mathrm{H}}, \mathrm{kcal} \mathrm{mol}^{-1}\right)$ ). The electronic structure of $\mathrm{Ni}$ surface (different faces and defects), as well shown in the literature, influenced the rates of carbon formation and diffusion on the $\mathrm{Ni}$ surface and towards the support during both $\mathrm{CH}_{4}$ decomposition and Boudouard reaction [58-65]. The morphological differences presented in the $\mathrm{CeO}_{2}$ carrier through SEM images (Figure S3) seem to play a role for the induced differences in the electronic structure of the Ni surface (Figure 1), as reported also in previous publications $[27,46]$. HR-TEM (Figure S2) also suggested different morphologies for the $\mathrm{Ni}$ nanoparticles for the given $\mathrm{Ni} / \mathrm{CeO}_{2}-\mathrm{HT}$ catalyst, where ceria preparation method also influenced the mean Ni particle size as illustrated in Figure 9. The amount of carbon measured after 
$12 \mathrm{~h}$ of DRM (Figure 9, Table S5), and the transient results of $\mathrm{CH}_{4}$ and $\mathrm{CO}$ decomposition reactions (Figures 5-8), tend therefore to suggest that the different morphology of ceria, as the result of different preparation method applied, induced Ni morphological/surface structural differences, thus surface nickel electronic modifications. These in turn govern the DRM activity behavior and carbon deposition rate of the various ceria-supported Ni catalysts [58].

Based on the $\mathrm{CH}_{4}$-activity results reported in Figure 2 and the $\mathrm{Ni}$ dispersion values over the same catalysts (Table S1), it appears that $\mathrm{Ni} / \mathrm{CeO}_{2}-\mathrm{HT}$ contained a smaller number of active sites than $\mathrm{Ni} / \mathrm{CeO}_{2}-\mathrm{SG}$ catalyst. On the other hand, the former catalyst produced more carbon (larger carbon accumulation rates) under DRM reaction conditions (Figures 3 and 9), whereas the opposite was seen under transient methane decomposition reaction conditions (Figure 5); the initial rates of $\mathrm{CH}_{4}$ dissociation to $\mathrm{H}_{2}$ and the deposited amount of carbon (Figure 5D) were higher on $\mathrm{Ni} / \mathrm{CeO}_{2}-\mathrm{HT}$ than $\mathrm{Ni} / \mathrm{CeO}_{2}-\mathrm{SG}$ catalysts (Table 1). As illustrated in Figure 9, there seemed to be no clear relationship between $\mathrm{d}_{\mathrm{CeO} 2}$ and $\mathrm{d}_{\mathrm{Ni}}$ and the amount of carbon deposition for at least $12 \mathrm{~h}$ after DRM. As is discussed below, the carbon formation and removal rates during DRM cannot be influenced only by the Ni metal and ceria support particle size in a clear monotonic way. The Ni-C strength, diffusion of carbon species on the Ni surface, and oxygen diffusion from the ceria support that the Ni phase and Ni-ceria interface (where carbon is formed) should all influence carbon deposition rate [46].

A possible explanation on the above results regarding carbon deposition on $\mathrm{Ni} / \mathrm{CeO}_{2}$ as influenced differently by the DRM, $\mathrm{CO} / \mathrm{He}$, and $\mathrm{CH}_{4} / \mathrm{He}$ reaction conditions seems to be the competition of $\mathrm{CH}_{4}$ and $\mathrm{CO}$ for the same $\mathrm{Ni}$ catalytic active sites, even though under DRM higher energy barriers are needed during the first and second steps of $\mathrm{CH}_{4}$ dissociation $\left(\mathrm{CH}_{4} \rightarrow \mathrm{CH}_{3}+\mathrm{H}\right.$ and $\left.\mathrm{CH}_{3} \rightarrow \mathrm{CH}_{2}+\mathrm{H}\right)$, and carbon dimer formation ( $\mathrm{C}_{2}$, carbon dimer is the first crucial step for inactive carbon formation). It was reported that both $\mathrm{CH}_{4}$ and $\mathrm{CO}$ preferentially dissociate on $\mathrm{Ni}(111)$ surface, with the former to also favorably dissociate on $\mathrm{Ni}(100)$ and $\mathrm{Ni}(110)$ surfaces to a similar extent [66-74].

The main focus of this work was the effect of preparation method of $\mathrm{CeO}_{2}$ used as support of $\mathrm{Ni}\left(5 \mathrm{wt} \% \mathrm{Ni} / \mathrm{CeO}_{2}\right)$ on the carbon deposition rates of the main routes $\left(\mathrm{CH}_{4}\right.$ decomposition and reverse Boudouard reaction), and on carbon removal rate (participation of support's $\mathrm{O}_{\mathrm{L}}$ ). It was shown that the preparation method influenced the Ni particle size and its morphology, and in turn its surface electronic structure, thus its catalytic performance for the DRM reaction at $750{ }^{\circ} \mathrm{C}$. The various temperature-programmed and step-gas concentration transient experiments (including the use of isotopes) provided important information for the better understanding of the carbon pathways during DRM, to be discussed next.

\subsection{Rates of Carbon Deposition and Removal under DRM Reaction Conditions}

As mentioned in the Introduction section, supported Ni catalysts suffer from large amounts of carbon deposition under DRM reaction conditions. The amount of carbon deposited over the catalytic surface should be considered as the net rate between carbon formation $\left(\mathrm{CH}_{4}\right.$ decomposition and Boudouard reaction) and the carbon removal (e.g., participation of support's lattice oxygen). The carbon removal rate via the participation of lattice oxygen was probed by the transient response curves depicted in Figure $8 \mathrm{~B}$ after partially exchanging active ceria support lattice ${ }^{16} \mathrm{O}_{\mathrm{L}}$ with ${ }^{18} \mathrm{O}_{\mathrm{L}}$. The carbon removal rate by this chemical step can be written to a first approximation as shown by the following Equation (1):

$$
\mathrm{R}_{\mathrm{C} 18 \mathrm{O}}(\mathrm{t})=\mathrm{k} \theta_{\mathrm{OL}}(\mathrm{t}) \theta_{\mathrm{C}}(\mathrm{t})
$$

where $\mathrm{k}$ is an effective rate constant for the reaction step (2), $\theta_{\mathrm{OL}}$ is the surface coverage of support lattice oxygen able to participate in reaction step (2), and $\theta_{C}$ is the surface coverage of carbon formed during DRM. In Equation (1), k might be considered as an average reactivity of more than one kind of carbon, whilst $\theta_{\mathrm{OL}}(\mathrm{t})$ is also determined by the rate of surface $\mathrm{O}_{\mathrm{L}}$ diffusion towards carbon. These two important kinetic parameters describing the rate of carbon gasification via Equation (1) are likely to depend on the $\mathrm{Ni}$ particle size/morphology as well as $\mathrm{CeO}_{2}$ primary particle size. 


$$
\mathrm{C}-\mathrm{s}+{ }^{18} \mathrm{O}_{-} \mathrm{L} \rightarrow \mathrm{C}^{18} \mathrm{O}(\mathrm{g})+\mathrm{s}+\mathrm{Vo}
$$

For reaction step (2), s is a catalytic site at the metal-support interface, the support or both, and $\mathrm{V}_{\mathrm{O}}$ is a surface oxygen vacancy of ceria support.

Initial carbon formation rates (recorded over a clean catalyst surface) and total amount of carbon accumulated during $30 \mathrm{~min}$ treatment of the catalysts were measured by performing transient experiments at $750{ }^{\circ} \mathrm{C}$ with $20 \mathrm{vol} \%$ of $\mathrm{CH}_{4}$ reactant in the feed (Figure 5), similar to DRM conditions, and by the reverse Boudouard reaction or the CO dissociation alone (Figure 6), using $20 \mathrm{vol} \% \mathrm{CO}$ (similar composition obtained in the DRM depicted in Figure 2). In addition, the individual amount of carbon derived from each route $\left(\mathrm{CH}_{4}\right.$ vs. $\left.\mathrm{CO}\right)$ when both gases were present in the feed stream was also estimated for probing any synergy effects on the accumulation of carbon (Figure 7).

It is clearly shown that both the initial rate of carbon formation (Figures $5 \mathrm{~A}$ and $6 \mathrm{~A}$ ) and the total amount of carbon formed (Table S5) over the four catalytic surfaces was at least 10 times larger in the case of $\mathrm{CH}_{4}$ decomposition compared to the reverse Boudouard reaction. This result is in very good agreement with the TPO results obtained following the isotopic DRM reaction $\left({ }^{13} \mathrm{CO}_{2} /{ }^{12} \mathrm{CH}_{4} / \mathrm{He}\right.$, Figure 4) and the isotopic ${ }^{13} \mathrm{CO} /{ }^{12} \mathrm{CH}_{4} / \mathrm{He}$ experiment (Figure 7), which both quantified the origin of carbon accumulation. Thus, the first conclusion is that $\mathrm{CH}_{4}$ activation route was dominant and the one controlling the rate of carbon formation, however, the competition of $\mathrm{CH}_{4}$ and $\mathrm{CO}$ activation for same catalytic sites, as clearly demonstrated, should be highly considered. In particular, the $\mathrm{Ni} / \mathrm{CeO}_{2}-\mathrm{HT}$ catalyst $\left(\mathrm{CeO}_{2}\right.$ prepared by the hydrothermal method) led to a smaller ( 1.8 times) initial rate of carbon formation via $\mathrm{CH}_{4}$ decomposition (Figure $5 \mathrm{~A}$ ) and $\mathrm{CO}$ dissociation ( $\sim 3.5$ times, Figure $6 \mathrm{~A}$ ) compared to the $\mathrm{Ni} / \mathrm{CeO}_{2}-\mathrm{TD}$ and $\mathrm{Ni} / \mathrm{CeO}_{2}-\mathrm{PT}$ catalysts, respectively. At this point it would be of interest to mention the effect of DRM reaction temperature on the origin of carbon deposition $\left(\mathrm{CH}_{4} \mathrm{vs} . \mathrm{CO}_{2}\right.$ activation route). Vasiliades et al. $[17,20]$ reported similar ${ }^{12} \mathrm{CH}_{4} /{ }^{13} \mathrm{CO}_{2} / \mathrm{He}$ isotopic DRM experiments as those reported in Section 2.6.2 (Figure 4) at 550 and $750{ }^{\circ} \mathrm{C}$ over $5 \mathrm{wt} \% \mathrm{Ni} / \mathrm{Ce}_{1-\mathrm{x}} \mathrm{M}_{\mathrm{x}} \mathrm{O}_{2}\left(\mathrm{M}=\mathrm{Zr}^{4+}\right.$, $\mathrm{Pr}^{3+}$ ) catalysts, the support of which (including pure $\mathrm{CeO}_{2}$ ) was prepared by the citrate sol-gel method. It was illustrated that at the low-T of $550{ }^{\circ} \mathrm{C}$, a higher contribution to carbon deposition was obtained via the $\mathrm{CO}_{2}$ activation route (reverse Boudouard reaction: $2 \mathrm{CO} \rightarrow \mathrm{CO}_{2}+\mathrm{C}$ ) as opposed to the reaction $\mathrm{T}$ of $750{ }^{\circ} \mathrm{C}$.

A careful comparison could be also made on the transient rates of $\mathrm{CO}$ formation during the $\mathrm{CH}_{4} / \mathrm{He}$ treatment (Figure $5 \mathrm{C}$ ), where the $\mathrm{Ni} / \mathrm{CeO}_{2}-\mathrm{HT}$ catalyst revealed significantly larger initial rate ( 1.5 times) of its labile oxygen towards carbon gasification to $\mathrm{CO}(\mathrm{g})$ compared to the $\mathrm{Ni} / \mathrm{CeO}_{2}-\mathrm{PT}$ and $\mathrm{Ni} / \mathrm{CeO}_{2}-\mathrm{TD}$ catalysts, and even larger ( $\sim 3$ times) in the case of $\mathrm{Ni} / \mathrm{CeO}_{2}-\mathrm{SG}$ catalyst. The latter results are in a good agreement with the experimental findings shown in Figure 8B, where gasification of the formed carbon towards $\mathrm{C}^{18} \mathrm{O}(\mathrm{g})$ formation under DRM reaction conditions takes place by the participation of support's ${ }^{18} \mathrm{O}_{\mathrm{L}}$. The amount of available labile oxygen for ${ }^{16} \mathrm{O} /{ }^{18} \mathrm{O}$ isotopic exchange was found to be similar for the four supported Ni catalysts, a fact that suggests that morphological differences in their metal and support do not influence this specific process at $750{ }^{\circ} \mathrm{C}$.

Considering the transient rates of $\mathrm{C}^{18} \mathrm{O}(\mathrm{g})$ obtained over the four catalytic systems (Figure 8B), it was apparent that $\mathrm{Ni} / \mathrm{CeO}_{2}$ - $\mathrm{HT}$ catalyst had activated a higher amount of lattice ${ }^{18} \mathrm{O}\left(11.4 \mathrm{mmol} \mathrm{g}^{-1}\right)$ by a factor of $\sim 1.1$ compared to $\mathrm{Ni} / \mathrm{CeO}_{2}-\mathrm{SG}\left(10.2 \mathrm{mmol} \mathrm{g}^{-1}\right.$, Table S6). Given the fact that the amount of carbon accumulated during DRM after $12 \mathrm{~h}$ was $\sim 1.5$ times larger in the case of $\mathrm{Ni} / \mathrm{CeO}_{2}-\mathrm{HT}$ compared to $\mathrm{Ni} / \mathrm{CeO}_{2}-\mathrm{SG}$ (see Section 2.6.1), it might be suggested that the effective rate constant $\mathrm{k}$ (Equation (1)) must be considered larger in the former than the latter catalyst. This result is important since it can prove that during DRM, the rate of carbon deposition on $\mathrm{Ni} / \mathrm{CeO}_{2}-\mathrm{HT}$ must be considered larger than on $\mathrm{Ni} / \mathrm{CeO}_{2}-\mathrm{SG}$, a result in harmony with the transient $\mathrm{CH}_{4}$ decomposition studies described in Section 2.6.3 (Figure 5A). Moreover, considering the integral rates of $\mathrm{CH}_{4}$ conversion reported in Figure 2A, the carbon deposited by $\mathrm{CH}_{4}$ during the $2 \mathrm{~min}$ transient shown in Figure $8 \mathrm{~B}$ (end of rate of carbon removal by ${ }^{18} \mathrm{O}$ lattice oxygen) could be estimated. Then, the ratio of the amount of carbon removed by ${ }^{18} \mathrm{O}$ lattice oxygen as $\mathrm{C}^{18} \mathrm{O}$ (see Figure $8 \mathrm{~B}$, Table S6) to the amount of carbon deposited via 
$\mathrm{CH}_{4}$ decomposition could be estimated. This ratio was found to follow the order: $\mathrm{CeO}_{2}-\mathrm{HT}>\mathrm{CeO}_{2}-\mathrm{TD}$ $>\mathrm{CeO}_{2}-\mathrm{SG}>\mathrm{CeO}_{2}-\mathrm{PT}$. The implication of this is that the reason that $\mathrm{Ni} / \mathrm{CeO}_{2}-\mathrm{HT}$ experienced the largest amount of carbon accumulation after $12 \mathrm{~h}$ in DRM (see Table S5), 3.8 times larger than that of $\mathrm{Ni} / \mathrm{CeO}_{2}-\mathrm{PT}$, should not be considered to be due to its inferior ability compared to the other ceria supports to provide mobile lattice oxygen for carbon gasification, at least for the first $30 \mathrm{~min}$ of TOS. It was suggested that carbon deposition and removal rates could change with longer time-on-stream as Ni surface and ceria support start to accommodate carbon deposits. Thus, deep understanding of the carbon accumulation with TOS and the intrinsic reasons for this is required for the given DRM ceria-supported Ni catalytic system.

It is noteworthy to be mentioned at this point that the differences in the delays of $\mathrm{C}^{18} \mathrm{O}(\mathrm{g})$ that appeared during the switch from the inert gas to the DRM feed gas among the different catalysts (Figure 8B) were due to the different transient kinetics of reduction of the initially oxidized Ni surface (after ${ }^{16} \mathrm{O} /{ }^{18} \mathrm{O}$ exchange), as previously reported [46,75].

The temperature-programmed oxidation profiles of the carbon accumulation over a reduced metal surface after $\mathrm{CH}_{4}$ decomposition or $\mathrm{CO}$ disproportionation alone or in the presence of both carbon sources illustrated that the co-presence of $\mathrm{CH}_{4}$ and $\mathrm{CO}$ largely enhances the rate of carbon deposition.

\section{Materials and Methods}

\subsection{Catalysts Synthesis}

\subsubsection{Cerium Dioxide $\left(\mathrm{CeO}_{2}\right)$ Supports}

\section{Sol-Gel Method}

The $\mathrm{CeO}_{2}$-SG metal oxide support was prepared using the modified citrate sol-gel method. The Ce metal precursor of $\mathrm{Ce}\left(\mathrm{NO}_{3}\right)_{3} \cdot 6 \mathrm{H}_{2} \mathrm{O}$ (Sigma Aldrich, $>99 \%$ purity) was diluted in a beaker containing $100 \mathrm{~mL}$ solution of 1:1 (v/v) ratio of deionized $\mathrm{H}_{2} \mathrm{O}$ and propanol-1. Citric acid (CA) was added for the creation of 1:1.5 $\mathrm{M}_{\mathrm{tot}}: \mathrm{CA}$, where $\mathrm{M}_{\text {tot }}$ refers to the total molar concentration of metal ions in the solution, and similarly, the $\mathrm{CA}$ (molar concentration of citric acid). The $\mathrm{pH}$ of the solution was continuously adjusted ( $\mathrm{pH} \sim 2.0$ ) by adding $\mathrm{HNO}_{3}(5 \mathrm{M})$, with the solution to be under stirring at $70^{\circ} \mathrm{C}$. The resulting gel-like yellowish material was dried at $120^{\circ} \mathrm{C}$ for $12 \mathrm{~h}$, prior to its thermal heating with $1{ }^{\circ} \mathrm{C} \mathrm{min}-1$ under static air from room $\mathrm{T}$ to $500^{\circ} \mathrm{C}$. The sample was then kept at $500^{\circ} \mathrm{C}$ for $6 \mathrm{~h}$ and its temperature was further increased to $750{ }^{\circ} \mathrm{C}\left(\beta=5^{\circ} \mathrm{C} \mathrm{min}-1\right)$ and kept for additional $4 \mathrm{~h}$ before cooled down to room $\mathrm{T}$.

\section{Thermal Decomposition Method}

The $\mathrm{CeO}_{2}$-TD metal oxide support was prepared using the thermal decomposition method. An appropriate amount of $\mathrm{Ce}\left(\mathrm{NO}_{3}\right)_{3} \cdot 6 \mathrm{H}_{2} \mathrm{O}$ was dried in static air at $120^{\circ} \mathrm{C}$ for $12 \mathrm{~h}$, and after being cooled down to room $\mathrm{T}$, its temperature was increased with $1^{\circ} \mathrm{C} \mathrm{min}^{-1}$ to $500^{\circ} \mathrm{C}$, where it was kept for $6 \mathrm{~h}$. The temperature of the resulting material was then further increased to $750{ }^{\circ} \mathrm{C}\left(\beta=5^{\circ} \mathrm{C} \min ^{-1}\right)$, where it was kept for additional $4 \mathrm{~h}$ before cooled down to room $\mathrm{T}$.

\section{Hydrothermal Method}

The $\mathrm{CeO}_{2}$-HT metal oxide support was prepared using the hydrothermal method. During this method, $40 \mathrm{M} \mathrm{NaOH}(\mathrm{pH} \sim 12.5)$ and $0.13 \mathrm{MCe}\left(\mathrm{NO}_{3}\right)_{3} \cdot 6 \mathrm{H}_{2} \mathrm{O}$ aqueous solutions were mixed (75 mL: $\left.175 \mathrm{~mL}\right)$, under vigorous stirring until a purplish milky slurry was formed. The milky slurry with total volume of $250 \mathrm{~mL}$ was kept under continuous stirring for $1 \mathrm{~h}$ and then transferred in a $1 \mathrm{~L}$ Teflon bottle and heated for $48 \mathrm{~h}$ at $90^{\circ} \mathrm{C}$. The reaction product was then cooled down to room temperature and the solid product was collected by filtration. The collected solid was rinsed with deionized water until $\mathrm{pH}$ neutralization to remove any co-precipitate salts. Drying and calcination procedures were performed as described in the thermal decomposition method. 
Precipitation Method

The $\mathrm{CeO}_{2}-\mathrm{PT}$ metal oxide support was prepared using the precipitation method. In the latter method, ammonia solution $(25 \% v / v)$ as precipitation agent was added dropwise at room temperature and under continuous stirring in a $0.5 \mathrm{M}$ aqueous solution of $\mathrm{Ce}\left(\mathrm{NO}_{3}\right)_{3} \cdot 6 \mathrm{H}_{2} \mathrm{O}$ until $\mathrm{pH}$ reached the value of 10 , conditions that were controlled for $3 \mathrm{~h}$. The resulting solution was then filtered, and the precipitate material was dried and calcined as described in the thermal decomposition method.

\subsubsection{Wetness Impregnation of $\mathrm{CeO}_{2}$ Supports with $\mathrm{Ni}\left(5 \mathrm{wt} \% \mathrm{Ni} / \mathrm{CeO}_{2}\right)$}

The resulting $\mathrm{CeO}_{2}$ supports from the various synthesis procedures were grinded prior to $\mathrm{Ni}$ metal deposition. A given amount of each of the oxidic ceria support was diluted in an aqueous solution of $\mathrm{Ni}\left(\mathrm{NO}_{3}\right)_{2} \cdot 6 \mathrm{H}_{2} \mathrm{O}$ (Sigma-Aldrich, $>99 \%$ purity) so as to be impregnated with $5 \mathrm{wt} \% \mathrm{Ni}$ nominal loading. The resulting slurry was dried overnight at $120^{\circ} \mathrm{C}$, followed by cooling to room $\mathrm{T}$. The temperature of the solid was then increased under static air to $750^{\circ} \mathrm{C}$, where it was kept for $4 \mathrm{~h}$. The resulting material was named "fresh catalyst", and prior to any catalytic measurements it was in situ reduced in pure $\mathrm{H}_{2}$ gas $\left(1 \mathrm{bar}, 50 \mathrm{NmL} \min ^{-1}\right)$ at $700{ }^{\circ} \mathrm{C}$ for $2 \mathrm{~h}$.

\subsection{Catalysts Characterization}

\subsubsection{Powder X-ray Diffraction (XRD)}

Powder X-ray diffractograms of the calcined $\mathrm{CeO}_{2}$-supported $\mathrm{Ni}$ catalysts were recorded by using a Shimadzu 6000 Series diffractometer (CuKa radiation, $\lambda=0.15418 \mathrm{~nm}$, Kyoto, Japan) in the $20-80^{\circ} 2 \theta$ range $\left(2^{\circ} \mathrm{min}^{-1}, 0.02^{\circ}\right.$ increment). By using the Scherrer equation [17], the lattice parameter $(\alpha, \AA)$, the mean primary crystallite size $\left(\mathrm{d}_{\mathrm{c}}, \mathrm{nm}\right)$ of the ceria pseudo-cubic structure, and the mean crystal size of $\mathrm{NiO}$ were estimated. The latter was used to estimate the Ni mean particle size $\left(\mathrm{d}_{\mathrm{Ni}}, \mathrm{nm}\right)$ as of Equation (3), after the assumption that $\mathrm{Ni}$ and $\mathrm{NiO}$ preserve the same particle geometrical shape:

$$
\mathrm{d}(\mathrm{Ni}, \mathrm{nm})=\mathrm{d}(\mathrm{NiO}, \mathrm{nm}) \times 0.847 .
$$

\subsubsection{Surface Texture (BET/BJH)}

The BET specific surface area (SSA, $\left.\mathrm{m}^{2} \mathrm{~g}^{-1}\right)$, the total pore volume $\left(\mathrm{V}_{\mathrm{p}}, \mathrm{cm}^{3} \mathrm{~g}^{-1}\right)$, and the mean pore size $\left(\mathrm{d}_{\mathrm{p}}, \mathrm{nm}\right)$ of the $\mathrm{CeO}_{2}$-supported nickel catalysts and their supports alone were determined based on $\mathrm{N}_{2}$ adsorption/desorption isotherms measured at $77 \mathrm{~K}$ with a Micromeritics Gemini 2360 surface area and pore size analyzer (Norcross, Georgia, United States). Prior to any measurements, the sample was degassed in $\mathrm{N}_{2}$ gas flow at $300{ }^{\circ} \mathrm{C}$ for $4 \mathrm{~h}$.

\subsection{3. $\mathrm{H}_{2}$ Temperature-Programmed Desorption (TPD)}

The effect of $\mathrm{Ni}$ supported on different $\mathrm{CeO}_{2}$ supports on the hydrogen chemisorption and desorption behavior was investigated by using the $\mathrm{H}_{2}$-TPD technique. A $0.3 \mathrm{~g}$ sample was first reduced in situ in hydrogen gas at $700^{\circ} \mathrm{C}$ for $2 \mathrm{~h}$ prior to He-purge and increase of its temperature to $750{ }^{\circ} \mathrm{C}$, until $\mathrm{H}_{2}$ signal reached its background value (desorption of any spilled-over hydrogen on the support). The reactor was then cooled down to room temperature and a switch from $\mathrm{He}$ to $0.5 \mathrm{vol} \% \mathrm{H}_{2} / \mathrm{He}$ (30 $\mathrm{min}$ ) gas mixture was performed. The catalyst was then purged for $10 \mathrm{~min}$ in He flow, and the temperature was subsequently increased to $750{ }^{\circ} \mathrm{C}\left(\mathrm{TPD}, \beta=30^{\circ} \mathrm{C} \mathrm{min}^{-1}, 50 \mathrm{NmL} \mathrm{min}{ }^{-1}\right.$ ). The $\mathrm{H}_{2}$ $(\mathrm{m} / \mathrm{z}=2)$ signal was continuously monitored with online mass spectrometer (MS, Balzers, Omnistar 1-200 amu, Pfeiffer Vacuum, Asslar, Germany), and the MS signal was converted into concentration (ppm) by using a certified standard gas mixture $\left(0.95 \mathrm{vol} \% \mathrm{H}_{2} / \mathrm{He}\right)$. The Ni dispersion $\left(\mathrm{D}_{\mathrm{Ni}}\right.$, \%) was estimated after assuming an $\mathrm{H}_{2}$ chemisorption stoichiometry of $\mathrm{H} / \mathrm{Ni}_{\mathrm{s}}=1$, where the Ni mean primary particle size $\left(\mathrm{d}_{\mathrm{Ni}}, \mathrm{nm}\right)$ was estimated by using the following Equation (4) [76]:

$$
\mathrm{d}_{\mathrm{Ni}}(\mathrm{nm})=0.97 / \mathrm{D}_{\mathrm{Ni}} \text {. }
$$




\subsubsection{Transmission Electron Microscopy (TEM)}

The fresh $5 \mathrm{wt} \% \mathrm{Ni} / \mathrm{CeO}_{2}$-HT supported Ni catalyst was characterized with a JEOL (JEM-2100) high-resolution transmission electron microscopy system (HR-TEM) (Tokyo, Japan), operated at $200 \mathrm{kV}$ (resolution point $0.23 \mathrm{~nm}$, lattice $0.14 \mathrm{~nm}$ ). Selected specimens were prepared by dispersion of the powdered catalyst in water, and spread onto a carbon-coated copper grid (200 mesh), while images were recorded by means of films (Kodak SO-163).

\subsubsection{Scanning Electron Microscopy (SEM)}

The morphology of the fresh $\mathrm{CeO}_{2}$-supported $\mathrm{Ni}$ solids was characterized by using scanning electron microscope (SEM, JEOL JSM-6610 LV, Tokyo, Japan), equipped with a BRUKER type QUANTAX 200 energy dispersive spectrometer (EDS). The effect of different method of synthesis of the $\mathrm{CeO}_{2}$ was studied using secondary electron images (SEI). EDS analysis was performed for determining the chemical composition of the solids.

\subsection{Catalytic Performance of $\mathrm{CeO}_{2}$-Supported Ni in DRM}

Catalytic measurements were performed using a Micro-activity reactor system (MA-REF from PID Eng \& Tech, Madrid, Spain) equipped with a tubular quartz reactor (i.d. $=6 \mathrm{~mm}$ ), and the experimental apparatus used was described elsewhere [20]. The catalytic bed was prepared by grinding (grain powder size less than $106 \mu \mathrm{m}$ ) and mixing an appropriate amount of $\mathrm{Ni} / \mathrm{CeO}_{2}$ catalyst with $\mathrm{SiC}$ ( 1 cat:1 $\mathrm{SiC}(w / w))$ in order to achieve a gas hourly space velocity (GHSV) of $\sim 30,000 \mathrm{~h}^{-1}$. Due to the differences in the ceria solid powder prepared by the four different methods, the amount of catalyst for each $\mathrm{Ni} / \mathrm{CeO}_{2}$ was varied $\left(\mathrm{W}_{\text {cat }}=0.072-0.167\right.$ ), while the total gas flow rate was kept the same $\left(50 \mathrm{NmL} \mathrm{min}{ }^{-1}\right)$. The catalytic performance of the solids was examined at $750{ }^{\circ} \mathrm{C}$ for $30 \mathrm{~min}$ with a DRM feed gas composition of $20 \mathrm{vol} \% \mathrm{CH}_{4} / 20 \mathrm{vol} \% \mathrm{CO}_{2} / 60 \mathrm{vol} \% \mathrm{He}$. The conversions of $\mathrm{CH}_{4}$ and $\mathrm{CO}_{2}\left(\mathrm{X}_{\mathrm{CH} 4}\right.$ and $\left.\mathrm{X}_{\mathrm{CO} 2}, \%\right)$ were calculated by using Equation (5). The effluent gas stream from the micro-reactor was analyzed through online MS and infrared gas analyzers (Horiba, VA-3000, Kyoto, Japan) for $\mathrm{H}_{2}(\mathrm{~m} / \mathrm{z}=2), \mathrm{CH}_{4}(\mathrm{~m} / \mathrm{z}=15)$ and $\mathrm{CO}, \mathrm{CO}_{2}$, respectively. Calibration of the signals from the MS and IR gas analyzers was made by using certified calibration gas mixtures $(1.06 \mathrm{vol} \% \mathrm{CO} / 1.02 \mathrm{vol} \%$ $\mathrm{CH}_{4} / 0.95 \mathrm{vol} \% \mathrm{H}_{2} / \mathrm{He}$ and $\left.2.55 \mathrm{vol} \% \mathrm{CO}_{2} / \mathrm{He}\right)$. The product yields $\left(\mathrm{Y}_{\mathrm{H} 2}\right.$ and $\left.\mathrm{Y}_{\mathrm{CO}}, \%\right)$ were estimated via Equations (6) and (7):

$$
\begin{gathered}
X_{Y}(\%)=\frac{F_{Y}^{\text {in }}-F_{Y}^{\text {out }}}{F_{Y}^{\text {in }}} \times 100 \\
Y_{\mathrm{H}_{2}}(\%)=\frac{F_{\mathrm{H}_{2}}^{\text {out }}}{2 F_{\mathrm{CH}}^{\text {in }}} \times 100 \\
Y_{\mathrm{CO}}(\%)=\frac{F_{\mathrm{CO}}^{\text {out }}}{F_{\mathrm{CH}}^{\text {in }}-F_{\mathrm{CO}}^{\text {in }}} \times 100
\end{gathered}
$$

where, $F^{\text {in }}$ and $F^{\text {out }}$ are the molar flow rates $\left(\mathrm{mol} \mathrm{s}^{-1}\right)$ of reactant $\mathrm{Y}\left(\mathrm{CH}_{4}\right.$ or $\left.\mathrm{CO}_{2}\right)$ and product $\left(\mathrm{H}_{2}\right.$ or $\mathrm{CO}$ ) at the inlet and outlet of the reactor, respectively. The $F^{\text {out }}$ was estimated based on the total volume flow rate at the outlet of the reactor (measured at 1 bar and room $\mathrm{T}$ ), and the mole fraction of the component measured by the above-mentioned gas analysis system.

\subsection{Characterization of Carbon Formed under Different Reaction Conditions}

\subsubsection{Dry Reforming of Methane $\left({ }^{12} \mathrm{CO}_{2} /{ }^{12} \mathrm{CH}_{4}\right)$ Reaction}

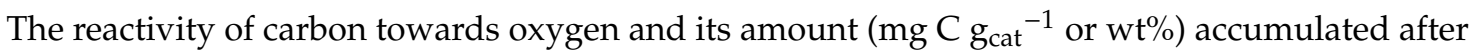
$12 \mathrm{~h}$ of DRM at $750^{\circ} \mathrm{C}$ over the catalysts investigated in this work were estimated by performing temperature-programmed oxidation (TPO) experiments following DRM. A purge with He (20 min) 
was applied after the $12 \mathrm{~h}$ DRM reaction with the reactor's temperature to increase to $800{ }^{\circ} \mathrm{C}$ until no MS signals was identified for $\mathrm{CH}_{4}, \mathrm{CO}_{2}, \mathrm{H}_{2}$, and $\mathrm{CO}$. The catalyst's temperature was then decreased to $100{ }^{\circ} \mathrm{C}$ followed by a feed gas switched from $\mathrm{He}$ to $10 \mathrm{vol} \% \mathrm{O}_{2} / \mathrm{He}\left(50 \mathrm{NmL} \mathrm{min}^{-1}\right)$. The catalyst's temperature was subsequently increased to $800{ }^{\circ} \mathrm{C}$ with a heating ramp of $30{ }^{\circ} \mathrm{C} \mathrm{min}^{-1}$ (TPO). During the latter switch, the signals of $\mathrm{CO}(\mathrm{m} / \mathrm{z}=28)$ and $\mathrm{CO}_{2}(\mathrm{~m} / \mathrm{z}=44)$ were continuously monitored with the $\mathrm{MS}$ and $\mathrm{CO} / \mathrm{CO}_{2}$ infrared gas analyzer, and then converted into mol\% based on certified calibration gas mixtures (1.06 vol\% CO/He and $\left.2.55 \mathrm{vol} \% \mathrm{CO}_{2} / \mathrm{He}\right)$.

\subsubsection{Isotopically Labelled Dry Reforming of Methane $\left({ }^{13} \mathrm{CO}_{2} /{ }^{12} \mathrm{CH}_{4}\right)$ Reaction}

Isotopically labelled DRM mixture $\left(5 \mathrm{vol} \%{ }^{13} \mathrm{CO}_{2} / 5 \mathrm{vol} \%{ }^{12} \mathrm{CH}_{4} / 45 \mathrm{vol} \% \mathrm{Ar} / 45 \mathrm{vol} \% \mathrm{He} ; 50 \mathrm{NmL} \mathrm{min}^{-1}\right.$; GHSV $\sim 30,000 \mathrm{~h}^{-1}$ ) was used for $30 \mathrm{~min}$ at $750^{\circ} \mathrm{C}$, followed by TPO, in order to investigate the relative contribution of $\mathrm{CH}_{4}$ and $\mathrm{CO}_{2}$ activation routes towards carbon accumulation ( $\mu \mathrm{mol} \mathrm{g}^{-1}$ and $\mathrm{mg} \mathrm{g}_{\mathrm{cat}}{ }^{-1}$ ) over the examined ceria-supported Ni catalytic systems. The ${ }^{12} \mathrm{C}$-containing TPO traces referred to the $\mathrm{CH}_{4}$ activation route contribution on the amount of carbon, whereas the ${ }^{13} \mathrm{C}$-containing TPO traces referred to the $\mathrm{CO}_{2}$ activation route. More precisely, after $30 \mathrm{~min}$ in DRM, a He purge was performed for 10 min prior to the temperature increase to $800{ }^{\circ} \mathrm{C}$ (until no MS signals for $\mathrm{CO}$ and $\mathrm{CO}_{2}$ were observed). The reactor was then cooled down to $200^{\circ} \mathrm{C}$, and the feed gas was switched from He to $10 \mathrm{vol} \% \mathrm{O}_{2} / \mathrm{He}\left(50 \mathrm{NmL} \mathrm{min}{ }^{-1}\right)$, followed by TPO to $800^{\circ} \mathrm{C}\left(\beta=30^{\circ} \mathrm{C} \mathrm{min}^{-1}\right)$. The signals for ${ }^{12} \mathrm{CO}$, ${ }^{13} \mathrm{CO},{ }^{12} \mathrm{CO}_{2}$, and ${ }^{13} \mathrm{CO}_{2}(\mathrm{~m} / \mathrm{z}=28,29,44$, and 45 , respectively) were continuously monitored by $\mathrm{MS}$ and their quantification (mol\%) was made by using certified gas mixtures $\left(1.06 \mathrm{vol} \%{ }^{12} \mathrm{CO} / \mathrm{He}, 10 \mathrm{vol} \%\right.$ ${ }^{13} \mathrm{CO} / \mathrm{Ar}, 2.55 \mathrm{vol} \%{ }^{12} \mathrm{CO}_{2} / \mathrm{He}$, and $10 \mathrm{vol} \%{ }^{13} \mathrm{CO}_{2} / \mathrm{Ar}$ ).

\subsubsection{Methane Decomposition $\left(\mathrm{CH}_{4} / \mathrm{He}\right)$ Reaction}

The reduced $\mathrm{CeO}_{2}$-supported $\mathrm{Ni}$ catalysts were exposed to $20 \% \mathrm{CH}_{4} / \mathrm{He}$ for $30 \mathrm{~min}$ in order to measure the initial rate of $\mathrm{CH}_{4}$ decomposition and its subsequent rate evolution, which is one of the main routes of inactive carbon formation under DRM conditions. The transient responses of $\mathrm{H}_{2}$ $(\mathrm{m} / \mathrm{z}=2), \mathrm{CH}_{4}(\mathrm{~m} / \mathrm{z}=15)$, and $\mathrm{CO}(\mathrm{m} / \mathrm{z}=28)$ were followed during the step-gas switch $\mathrm{He} \rightarrow 20 \%$

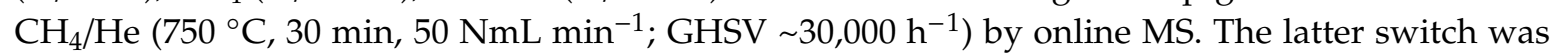
followed by a $10 \mathrm{~min}$ He purge, while the temperature was increased to $800^{\circ} \mathrm{C}$ (until background values were reached for the $\mathrm{CO}$ and $\mathrm{CO}_{2} \mathrm{MS}$ signals). The catalyst was then cooled down to $200^{\circ} \mathrm{C}$ and the

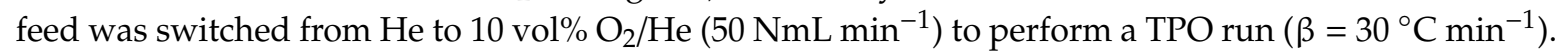
The transient evolution of $\mathrm{CO}(\mathrm{m} / \mathrm{z}=28)$ and $\mathrm{CO}_{2}(\mathrm{~m} / \mathrm{z}=44)$ was continuously monitored with MS, and their quantification was made using certified calibration gas mixtures $(1.06 \mathrm{vol} \% \mathrm{CO} / 1.02 \mathrm{vol} \%$ $\mathrm{CH}_{4} / 0.95 \mathrm{vol} \% \mathrm{H}_{2} / \mathrm{He}$ and $2.55 \mathrm{vol} \% \mathrm{CO}_{2} / \mathrm{He}$ ).

\subsubsection{Carbon Monoxide Dissociation (CO/He) Reaction}

The second main route of inactive carbon formation during DRM, that of reverse Boudouard reaction, was investigated by performing over the $5 \mathrm{wt} \% \mathrm{Ni} / \mathrm{CeO}_{2}$ catalysts the step-gas switch $\mathrm{He} \rightarrow$

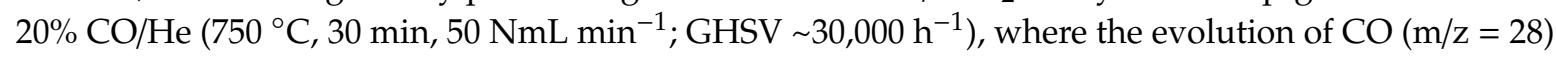
and $\mathrm{CO}_{2}(\mathrm{~m} / \mathrm{z}=44)$ were continuously monitored with MS. The latter gas switch was followed by a He purge $(10 \mathrm{~min})$ and temperature increase to $800{ }^{\circ} \mathrm{C}$, where the catalyst was kept at this temperature until the $\mathrm{CO}$ and $\mathrm{CO}_{2} \mathrm{MS}$ signals reached their respective background value. The reactor's temperature was then decreased to $200{ }^{\circ} \mathrm{C}$, where a switch to $10 \mathrm{vol} \% \mathrm{O}_{2} / \mathrm{He}\left(50 \mathrm{NmL} \mathrm{min}{ }^{-1}\right)$ gas mixture was made for a TPO run to $800{ }^{\circ} \mathrm{C}\left(\beta=30^{\circ} \mathrm{C} \mathrm{min}-1\right)$. During TPO, the mass numbers $(\mathrm{m} / \mathrm{z})$ of 28 and 44 were followed by MS, and quantification was made by considering certified calibration gas mixtures $\left(1.06 \mathrm{vol} \% \mathrm{CO} / \mathrm{He}\right.$ and $\left.2.55 \mathrm{vol} \% \mathrm{CO}_{2} / \mathrm{He}\right)$. 


\subsubsection{Isotopically Labelled Competitive $\left({ }^{13} \mathrm{CO} /{ }^{12} \mathrm{CH}_{4}\right)$ Reaction towards Carbon Formation}

The relative contribution of the two main routes towards inactive carbon accumulation under DRM reaction conditions $\left(\mathrm{CH}_{4}\right.$ decomposition and reverse Boudouard reaction) was investigated by exposing the catalysts over an isotopically labelled mixture consisting of $2.5 \mathrm{vol} \%{ }^{13} \mathrm{CO} / 2.5 \mathrm{vol} \%$ ${ }^{12} \mathrm{CH}_{4} / 2$ vol\% $\mathrm{Kr} / \mathrm{Ar} / \mathrm{He}\left(50 \mathrm{NmL} \mathrm{min}{ }^{-1}\right.$; GHSV $\left.\sim 30,000 \mathrm{~h}^{-1}\right)$ at $750{ }^{\circ} \mathrm{C}$ for $20 \mathrm{~min}$. The gas-flow was then switched to $\mathrm{He}$ for a $10 \mathrm{~min}$ purge and the temperature was increased to $800^{\circ} \mathrm{C}$ until the ${ }^{12} \mathrm{CO}$, ${ }^{13} \mathrm{CO},{ }^{12} \mathrm{CO}_{2}$, and ${ }^{13} \mathrm{CO}_{2} \mathrm{MS}$ signals reached their respective background value. The catalyst was then cooled in He flow to $200^{\circ} \mathrm{C}$ and a switch to $10 \mathrm{vol} \% \mathrm{O}_{2} / \mathrm{He}\left(50 \mathrm{NmL} \mathrm{min}^{-1}\right)$ gas mixture was made for a TPO run (increase $\mathrm{T}$ to $800{ }^{\circ} \mathrm{C}, \beta=30^{\circ} \mathrm{C} \mathrm{min}{ }^{-1}$ ). The effluent gas stream was continuously monitored by MS for ${ }^{12} \mathrm{CO},{ }^{13} \mathrm{CO},{ }^{12} \mathrm{CO}_{2}$, and ${ }^{13} \mathrm{CO}_{2}(\mathrm{~m} / \mathrm{z}=28,29,44$, and 45 , respectively), and quantification of the MS signals was made by using the previously mentioned (Section 4.4.2) calibration gas mixtures. It's worth mentioning that the ${ }^{12} \mathrm{C}$-containing TPO traces refer to the ${ }^{12} \mathrm{CH}_{4}$ contribution on the amount of carbon accumulation, whereas the ${ }^{13} \mathrm{C}$-containing TPO traces refer to the ${ }^{13} \mathrm{CO}$ route.

\subsection{Participation of Support's Lattice Oxygen in DRM Reaction Conditions}

The partial ${ }^{16} \mathrm{O} /{ }^{18} \mathrm{O}$ isotopic exchange of ceria support's lattice ${ }^{16} \mathrm{O}$ was performed over pre-reduced $\mathrm{Ni} / \mathrm{CeO}_{2}$ catalysts $\left(\mathrm{W}_{\mathrm{cat}}=0.02 \mathrm{~g}\right.$ ) at $750{ }^{\circ} \mathrm{C}$ for $10 \mathrm{~min}$ prior to the dry reforming of methane reaction. This designed experiment probes for the extent of contribution of support's lattice oxygen in the carbon-path under DRM conditions [18,19]. More precisely, after $2 \mathrm{~h}$ reduction of catalyst with pure $\mathrm{H}_{2}$ ( 1 bar) at $700{ }^{\circ} \mathrm{C}$, the feed was switched to $\mathrm{Ar}$ for $10 \mathrm{~min}$ with subsequent increase of the temperature to $750{ }^{\circ} \mathrm{C}$, until no $\mathrm{H}_{2}(\mathrm{~m} / \mathrm{z}=2),{ }^{16} \mathrm{O}_{2}(\mathrm{~m} / \mathrm{z}=32)$, and ${ }^{16} \mathrm{O}^{18} \mathrm{O}(\mathrm{m} / \mathrm{z}=34) \mathrm{MS}$ signals were recorded. The exchange of support lattice oxygen and the oxidation of $\mathrm{Ni} / \mathrm{NiO}_{x}$ to $\mathrm{Ni}^{18} \mathrm{O}$ with ${ }^{18} \mathrm{O}_{2}(\mathrm{~g})$ was then made by exposing the catalyst to $2 \mathrm{vol} \%{ }^{18} \mathrm{O}_{2} / 2$ vol $\% \mathrm{Kr} / \mathrm{Ar} / \mathrm{He}\left(10 \mathrm{~min}, 50 \mathrm{NmL} \mathrm{min}{ }^{-1}\right)$. During the exchange process, the signals of ${ }^{16} \mathrm{O}_{2},{ }^{16} \mathrm{O}^{18} \mathrm{O},{ }^{18} \mathrm{O}_{2}$, and $\mathrm{Kr}(\mathrm{m} / \mathrm{z}=32,34,36$, and 84, respectively) were recorded continuously with online MS, which then converted into concentration ( $\mathrm{mol} \%$ ) by using appropriate material balances [18] from which the amount of oxygen exchanged $\left(\mathrm{mol}^{16} \mathrm{O} \mathrm{g}^{-1}\right)$ can be estimated. A 10 min He purge then followed, and the feed gas was then switched to $20 \mathrm{vol} \% \mathrm{CH}_{4} / 20$ vol $\% \mathrm{CO}_{2} / \mathrm{He}\left(50 \mathrm{NmL} \mathrm{min}^{-1}\right)$. During the latter DRM reaction step, the MS signals of $30,44,46,48$, and $84\left(\mathrm{C}^{18} \mathrm{O}, \mathrm{C}^{16} \mathrm{O}_{2}, \mathrm{C}^{16} \mathrm{O}^{18} \mathrm{O}, \mathrm{C}^{18} \mathrm{O}_{2}\right.$, and $\mathrm{Kr}$, respectively) were continuously monitored, and then converted into concentration ( $\mathrm{mol} \%$ ) by using appropriate calibration gases. It was assumed same sensitivities for the $\mathrm{C}^{16} \mathrm{O}$ and $\mathrm{C}^{18} \mathrm{O}(\mathrm{m} / \mathrm{z}=30)$ gases. The contribution of $\mathrm{C}^{18} \mathrm{O}_{2}(\mathrm{~m} / \mathrm{z}=48)$ and $\mathrm{C}^{16} \mathrm{O}^{18} \mathrm{O}$ $(\mathrm{m} / \mathrm{z}=46)$ to the $\mathrm{m} / \mathrm{z}=30$ were carefully subtracted from the $\mathrm{m} / \mathrm{z}=30\left(\mathrm{C}^{18} \mathrm{O}\right)$ signal recorded by using a standard $\mathrm{C}^{16} \mathrm{O}_{2} / \mathrm{He}$ gas mixture and considering the same contribution of $\mathrm{m} / \mathrm{z}=44$ to $\mathrm{m} / \mathrm{z}=28$ for the $\mathrm{m} / \mathrm{z}=48$ and $\mathrm{m} / \mathrm{z}=46$ to $\mathrm{m} / \mathrm{z}=30$. The formation of $\mathrm{C}^{18} \mathrm{O}(\mathrm{g})$ during DRM, following the oxygen ${ }^{16} \mathrm{O} /{ }^{18} \mathrm{O}$ isotopic exchange step, is clearly described in our previous publications $[20,46]$, where ${ }^{18} \mathrm{O}_{\mathrm{L}}$ of support can react with carbon formed on the catalyst surface.

\section{Conclusions}

The main conclusions derived from the present work are as follows:

(a) The $5 \mathrm{wt} \% \mathrm{Ni}$ supported on $\mathrm{CeO}_{2}$ carriers prepared by four different methods exhibited obvious structural and morphological differences, which led to large differences in catalytic activity under DRM reaction conditions at $750{ }^{\circ} \mathrm{C}$.

(b) The $\mathrm{Ni} / \mathrm{CeO}_{2}-\mathrm{PT}$ (ceria was prepared by the precipitation method) exhibited the lowest amount of carbon formation among the four catalytic systems. A notable reduction of carbon deposition by $\sim 3.8,1.8$, and 1.4 times was observed after $12 \mathrm{~h}$ in DRM $\left(20 \mathrm{vol} \% \mathrm{CH}_{4}, \mathrm{CO}_{2} / \mathrm{CH}_{4}=1\right)$ compared to $\mathrm{Ni} / \mathrm{CeO}_{2}-\mathrm{HT}, \mathrm{Ni} / \mathrm{CeO}_{2}-\mathrm{TD}$, and $\mathrm{Ni} / \mathrm{CeO}_{2}-\mathrm{SG}$, respectively. This precipitation route might lead also to lower carbon deposits in DRM for other $\mathrm{CeO}_{2}$-based supported $\mathrm{Ni}$ catalysts in attempting to develop low-carbon resistant DRM catalytic systems in the future. 
(c) Based on various transient and other isotopic experiments, it was shown that a large pool of oxygen contributes to the gasification of carbon formed in DRM towards the formation of CO, thus offering an important path for carbon removal from the catalyst during DRM.

(d) The origin of carbon deposition was found to be largely determined by the $\mathrm{CH}_{4}$ activation route in all four catalytic systems but to a different extent.

(e) The $\mathrm{Ni} / \mathrm{CeO}_{2}-\mathrm{HT}$ and $\mathrm{Ni} / \mathrm{CeO}_{2}-\mathrm{PT}$ catalysts presented similar amount of $\mathrm{CH}_{4}$ decomposed $\left(\mathrm{CH}_{4} / \mathrm{He}\right.$ reaction), which was found to increase by $\sim 1.6$ and 1.3 times for $\mathrm{Ni} / \mathrm{CeO}_{2}-\mathrm{TD}$ and $\mathrm{Ni} / \mathrm{CeO}_{2}$-SG catalysts. On the other hand, the ratio between the $\mathrm{CO}$ formation and $\mathrm{CH}_{4}$ consumption was found to be the same for $\mathrm{Ni} / \mathrm{CeO}_{2}-\mathrm{HT}$ and $\mathrm{Ni} / \mathrm{CeO}_{2}-\mathrm{PT}$ but significantly lower in the case of $\mathrm{Ni} / \mathrm{CeO}_{2}-\mathrm{TD}$ and $\mathrm{Ni} / \mathrm{CeO}_{2}-\mathrm{SG}$ catalysts, indicating the higher ability of the former solids to remove deposited carbon by the participation of their ceria support lattice oxygen.

(f) During the reverse Boudouard reaction ( $\mathrm{CO} / \mathrm{He}$ reaction), the largest amount of carbon deposited was found to be on $\mathrm{Ni} / \mathrm{CeO}_{2}-\mathrm{PT}$ followed by $\mathrm{Ni} / \mathrm{CeO}_{2}-\mathrm{TD}, \mathrm{Ni} / \mathrm{CeO}_{2}-\mathrm{HT}$, and $\mathrm{Ni} / \mathrm{CeO}_{2}-\mathrm{SG}$ solids.

(g) Despite the fact that on $\mathrm{Ni} / \mathrm{CeO}_{2}-\mathrm{HT}$ a lesser amount of carbon was deposited during $\mathrm{CH}_{4}$ decomposition, during $\mathrm{CO}$ disproportionation compared to the other catalysts, the amount of carbon deposition observed after $12 \mathrm{~h}$ in DRM $\left(20 \mathrm{vol} \% \mathrm{CH}_{4}, \mathrm{CO}_{2} / \mathrm{CH}_{4}=1\right)$ was the largest. This behavior could be justified by the enhancement of carbon deposition in the co-presence of $\mathrm{CH}_{4}$ and $\mathrm{CO}$ which occurs in a larger extent over $\mathrm{Ni} / \mathrm{CeO}_{2}-\mathrm{HT}$ as proved experimentally.

Supplementary Materials: The following are available online at http://www.mdpi.com/2073-4344/9/7/621/s1, Figure S1: Powder X-ray diffractograms of $5 \mathrm{wt} \% \mathrm{Ni}$ supported on (a) $\mathrm{CeO}_{2}-\mathrm{TD}$, (b) $\mathrm{CeO}_{2}-\mathrm{PT}$, (c) $\mathrm{CeO}_{2}-\mathrm{HT}$ and (d) $\mathrm{CeO}_{2}-\mathrm{SG}$ carriers in the (A) $20-70^{\circ} 2 \theta$ and (B) $35-45^{\circ} 2 \theta$ region (diffraction peaks of $\mathrm{NiO}$ ), Figure S2: Representative HR-TEM images of the calcined (air, $750{ }^{\circ} \mathrm{C} / 4 \mathrm{~h}$ ) $5 \mathrm{wt} \% \mathrm{Ni} / \mathrm{CeO}_{2}-\mathrm{HT}$ catalyst. Left graph: magnification at $50 \mathrm{~nm}$ unit scale; Right graph: magnification at $10 \mathrm{~nm}$ unit scale, Figure S3: SEM images of the fresh Ni/CeO ${ }_{2}-\mathrm{SG}$ (top left), $\mathrm{Ni} / \mathrm{CeO}_{2}-\mathrm{PT}$ (top right), $\mathrm{Ni} / \mathrm{CeO}_{2}-\mathrm{HT}$ (down left) and $\mathrm{Ni} / \mathrm{CeO}_{2}-\mathrm{TD}$ (down right), Table S1: Textural and structural characterization of $5 \mathrm{wt} \% \mathrm{Ni} / \mathrm{CeO}_{2}(-\mathrm{TD},-\mathrm{PT},-\mathrm{HT}$ and -SG) DRM fresh catalysts, Table S2: Catalytic activity in terms of $\mathrm{CH}_{4}, \mathrm{CO}_{2}$ conversion $\left(\mathrm{X}_{\mathrm{CH}}, \mathrm{X}_{\mathrm{CO} 2}, \%\right), \mathrm{H}_{2}$ Yield (\%) and $\mathrm{H}_{2} / \mathrm{CO}$ gas product ratio obtained after $30 \mathrm{~min}$ in DRM at $750{ }^{\circ} \mathrm{C}$ for the four ceria supports prepared by different methods, Table S3: Catalytic stability performance in terms of $\mathrm{CH}_{4}, \mathrm{CO}_{2}$ conversion $\left(\mathrm{X}_{\mathrm{CH} 4}, \mathrm{X}_{\mathrm{CO} 2}, \%\right), \mathrm{H}_{2}$ Yield (\%), $\mathrm{H}_{2} / \mathrm{CO}$ gas product ratio and carbon deposition (mg C g ${ }^{-1}$ cat) obtained during DRM $\left(20 \% \mathrm{CH}_{4} / 20 \% \mathrm{CO}_{2} / \mathrm{He}\right)$ at $750{ }^{\circ} \mathrm{C}$ over the $5 \mathrm{wt} \% \mathrm{Ni} / \mathrm{CeO}_{2}-\mathrm{PT}$ solid, Table S4: Catalytic activity in terms of $\mathrm{CH}_{4}, \mathrm{CO}_{2}$ conversion $\left(\mathrm{X}_{\mathrm{CH} 4}, \mathrm{X}_{\mathrm{CO} 2}, \%\right), \mathrm{H}_{2}$ Yield (\%) and $\mathrm{H}_{2} / \mathrm{CO}$ gas product ratio obtained after $30 \mathrm{~min}$ in DRM $\left(5 \mathrm{vol} \%{ }^{13} \mathrm{CO}_{2} / 5 \mathrm{vol} \%{ }^{12} \mathrm{CH}_{4} / \mathrm{He}\right)$ at $750{ }^{\circ} \mathrm{C}$, Table S5: Carbon accumulation ( $\mathrm{mg} \mathrm{C}_{\mathrm{cat}}{ }^{-1}$ ) estimated via TPO followed individual reactions over all catalysts at $750{ }^{\circ} \mathrm{C} ; 20 \mathrm{vol} \%$ $\mathrm{CO}_{2} / 20 \mathrm{vol} \% \mathrm{CH}_{4} / \mathrm{He}(12 \mathrm{~h}), 5 \mathrm{vol} \%{ }^{13} \mathrm{CO}_{2} / 5 \mathrm{vol} \%{ }^{12} \mathrm{CH}_{4} / \mathrm{He}(30 \mathrm{~min}), 20 \mathrm{vol} \% \mathrm{CH}_{4} / \mathrm{He}(30 \mathrm{~min}), 20 \mathrm{vol} \% \mathrm{CO} / \mathrm{He}$ (30 min), $2.5 \mathrm{vol} \%{ }^{13} \mathrm{CO} / 2.5 \mathrm{vol} \%{ }^{12} \mathrm{CH}_{4} / \mathrm{He}(20 \mathrm{~min})$, Table S6: $18 \mathrm{O}$ consumption $\left(\mathrm{mmol} \mathrm{g}^{-1}\right)$ during ${ }^{16} \mathrm{O} /{ }^{18} \mathrm{O}$ exchange, $\mathrm{C}^{18} \mathrm{O}$ formation ( $\mathrm{mmol} \mathrm{g}{ }^{-1}$ ) during DRM following ${ }^{16} \mathrm{O} /{ }^{18} \mathrm{O}$ oxygen exchange, and $\mathrm{C}^{18} \mathrm{O} /{ }^{18} \mathrm{O}$ ratio.

Author Contributions: Conceptualization, A.M.E., V.N.S., and M.A.V.; methodology, A.M.E., V.N.S., and M.A.V.; validation, M.A.V. and C.M.D.; formal analysis, C.M.D.; investigation, C.M.D.; resources, A.M.E.; data curation, C.M.D.; writing — original draft preparation, M.A.V.; writing—review and editing, A.M.E.; visualization, A.M.E. and M.A.V.; supervision, A.M.E. and M.A.V.; project administration, M.A.V. and C.M.D.; funding acquisition, A.M.E.

Funding: This research was funded by the Research Committee of the University of Cyprus.

Acknowledgments: The authors are grateful to Maria Kollia (Research Associate) of the University of Patras for performing the HR-TEM studies.

Conflicts of Interest: The authors declare no conflict of interest.

\section{References}

1. Barbosa, L.C.; Araújo, O.Q.F.; de Medeiros, J.L. Carbon capture and adjustment of water and hydrocarbon dew-points via absorption with ionic liquid [Bmim] $\left[\mathrm{NTf}_{2}\right]$ in offshore processing of $\mathrm{CO}_{2}$-rich natural gas. J. Nat. Gas Sci. Eng. 2019, 66, 26-41. [CrossRef]

2. De Carvalho Reis, A.; de Medeiros, J.L.; Nunes, G.C.; Araújo, O.Q.F. Upgrading of natural gas ultra-rich in carbon dioxide: Optimal arrangement of membrane skids and polishing with chemical absorption. J. Clean. Prod. 2017, 165, 1013-1024. [CrossRef] 
3. De Oliveira Arinelli, L.; Trotta, T.A.F.; Teixeira, A.M.; de Medeiros, J.L.; Araújo, O.Q.F. Offshore processing of $\mathrm{CO}_{2}$ rich natural gas with supersonic separator versus conventional routes. J. Nat. Gas Sci. Eng. 2017, 46, 199-221. [CrossRef]

4. Lachén, J.; Durán, P.; Menéndez, M.; Peña, J.A.; Herguido, J. Biogas to high purity hydrogen by methane dry reforming in TZFBR $+\mathrm{MB}$ and exhaustion by Steam-Iron Process. Techno-economic assessment. Int. J. Hydrogen Energy 2018, 43, 11663-11675. [CrossRef]

5. Ugarte, P.; Durán, P.; Lasobras, J.; Soler, J.; Menéndez, M.; Herguido, J. Dry reforming of biogas in fluidized bed: Process intensification. Int. J. Hydrogen Energy 2017, 42, 13589-13597. [CrossRef]

6. Gao, J.; Hou, Z.; Lou, H.; Zheng, X. Dry $\left(\mathrm{CO}_{2}\right)$ Reforming. In Fuel Cells: Technologies for Fuel Processing; Elsevier: Amsterdam, The Netherlands, 2011; pp. 191-221. ISBN 9780444535634.

7. Navas-Anguita, Z.; Cruz, P.L.; Martín-Gamboa, M.; Iribarren, D.; Dufour, J. Simulation and life cycle assessment of synthetic fuels produced via biogas dry reforming and Fischer-Tropsch synthesis. Fuel 2019, 235, 1492-1500. [CrossRef]

8. Clarkson, J.; Ellis, P.R.; Humble, R.; Kelly, G.J.; McKenna, M.; West, J. Deactivation of alumina supported cobalt FT catalysts during testing in a Continuous-stirred tank reactor (CSTR). Appl. Catal. A Gen. 2018, 550, 28-37. [CrossRef]

9. Leonzio, G. State of art and perspectives about the production of methanol, dimethyl ether and syngas by carbon dioxide hydrogenation. J. CO2 Util. 2018, 27, 326-354. [CrossRef]

10. Venvik, H.J.; Yang, J. Catalysis in microstructured reactors: Short review on small-scale syngas production and further conversion into methanol, DME and Fischer-Tropsch products. Catal. Today 2017, 285, 135-146. [CrossRef]

11. Aramouni, N.A.K.; Touma, J.G.; Tarboush, B.A.; Zeaiter, J.; Ahmad, M.N. Catalyst design for dry reforming of methane: Analysis review. Renew. Sustain. Energy Rev. 2018, 82, 2570-2585. [CrossRef]

12. Jang, W.J.; Shim, J.O.; Kim, H.M.; Yoo, S.Y.; Roh, H.S. A review on dry reforming of methane in aspect of catalytic properties. Catal. Today 2018, 324, 15-26. [CrossRef]

13. Mah, A.X.Y.; Ho, W.S.; Bong, C.P.C.; Hassim, M.H.; Liew, P.Y.; Asli, U.A.; Kamaruddin, M.J.; Chemmangattuvalappil, N.G. Review of hydrogen economy in Malaysia and its way forward. Int. J. Hydrogen Energy 2019, 44, 5661-5675. [CrossRef]

14. Sovacool, B.K. Reviewing, Reforming, and Rethinking Global Energy Subsidies: Towards a Political Economy Research Agenda. Ecol. Econ. 2017, 135, 150-163. [CrossRef]

15. Damyanova, S.; Pawelec, B.; Arishtirova, K.; Fierro, J.L.G. Ni-based catalysts for reforming of methane with $\mathrm{CO}_{2}$. Int. J. Hydrogen Energy 2012, 37, 15966-15975. [CrossRef]

16. Usman, M.; Wan Daud, W.M.A.; Abbas, H.F. Dry reforming of methane: Influence of process parameters-A review. Renew. Sustain. Energy Rev. 2015, 45, 710-744. [CrossRef]

17. Makri, M.M.; Vasiliades, M.A.; Petallidou, K.C.; Efstathiou, A.M. Effect of support composition on the origin and reactivity of carbon formed during dry reforming of methane over $5 \mathrm{wt} \% \mathrm{Ni} / \mathrm{Ce}_{1-\mathrm{x}} \mathrm{M}_{\mathrm{x}} \mathrm{O}_{2-\delta}\left(\mathrm{M}=\mathrm{Zr}^{4+}\right.$, $\mathrm{Pr}^{3+}$ ) catalysts. Catal. Today 2016, 259, 150-164. [CrossRef]

18. Vasiliades, M.A.; Djinović, P.; Pintar, A.; Kovač, J.; Efstathiou, A.M. The effect of $\mathrm{CeO}_{2}-\mathrm{ZrO}_{2}$ structural differences on the origin and reactivity of carbon formed during methane dry reforming over $\mathrm{NiCo} / \mathrm{CeO}_{2}-\mathrm{ZrO}_{2}$ catalysts studied by transient techniques. Catal. Sci. Technol. 2017, 7, 5422-5434. [CrossRef]

19. Vasiliades, M.A.; Djinović, P.; Davlyatova, L.F.; Pintar, A.; Efstathiou, A.M. Origin and reactivity of active and inactive carbon formed during DRM over Ni/Ce ${ }_{0.38} \mathrm{Zr}_{0.62} \mathrm{O}_{2-\delta}$ studied by transient isotopic techniques. Catal. Today 2018, 299, 201-211. [CrossRef]

20. Vasiliades, M.A.; Makri, M.M.; Djinović, P.; Erjavec, B.; Pintar, A.; Efstathiou, A.M. Dry reforming of methane over $5 \mathrm{wt} \% \mathrm{Ni} / \mathrm{Ce}_{1-\mathrm{x}} \operatorname{Pr}_{\mathrm{x}} \mathrm{O}_{2-\delta}$ catalysts: Performance and characterisation of active and inactive carbon by transient isotopic techniques. Appl. Catal. B Environ. 2016, 197, 168-183. [CrossRef]

21. Simonov, M.N.; Rogov, V.A.; Smirnova, M.Y.; Sadykov, V.A. Pulse Microalorimetry Study of Methane Dry Reforming Reaction on Ni/Ceria-Zirconia Catalyst. Catalysts 2017, 7, 268. [CrossRef]

22. Pakhare, D.; Spivey, J. A review of dry $\left(\mathrm{CO}_{2}\right)$ reforming of methane over noble metal catalysts. Chem. Soc. Rev. 2014, 43, 7813-7837. [CrossRef]

23. Zhang, G.; Liu, J.; Xu, Y.; Sun, Y. A review of $\mathrm{CH}_{4}-\mathrm{CO}_{2}$ reforming to synthesis gas over Ni-based catalysts in recent years (2010-2017). Int. J. Hydrogen Energy 2018, 43, 15030-15054. [CrossRef] 
24. Muraza, O.; Galadima, A. A review on coke management during dry reforming of methane. Int. J. Energy Res. 2015, 39, 1196-1216. [CrossRef]

25. Arora, S.; Prasad, R. An overview on dry reforming of methane: Strategies to reduce carbonaceous deactivation of catalysts. RSC Adv. 2016, 6, 108668-108688. [CrossRef]

26. Lykaki, M.; Pachatouridou, E.; Iliopoulou, E.; Carabineiro, S.A.C.; Konsolakis, M. Impact of the synthesis parameters on the solid state properties and the CO oxidation performance of ceria nanoparticles. RSC Adv. 2017, 7, 6160-6169. [CrossRef]

27. Cortés Corberán, V.; Rives, V.; Stathopoulos, V. Recent Applications of Nanometal Oxide Catalysts in Oxidation Reactions. In Advanced Nanomaterials for Catalysis and Energy; Sadykov, V.A., Ed.; Elsevier: Amsterdam, The Netherlands, 2018; pp. 227-293. ISBN 978-0-12-814807-5.

28. Lykaki, M.; Pachatouridou, E.; Carabineiro, S.A.C.; Iliopoulou, E.; Andriopoulou, C.; Kallithrakas-Kontos, N.; Boghosian, S.; Konsolakis, M. Ceria nanoparticles shape effects on the structural defects and surface chemistry: Implications in $\mathrm{CO}$ oxidation by $\mathrm{Cu} / \mathrm{CeO}_{2}$ catalysts. Appl. Catal. B Environ. 2018, 230, 18-28. [CrossRef]

29. Zhang, D.; Du, X.; Shi, L.; Gao, R. Shape-controlled synthesis and catalytic application of ceria nanomaterials. Dalt. Trans. 2012, 41, 14455-14475. [CrossRef]

30. Tok, A.I.Y.; Boey, F.Y.C.; Dong, Z.; Sun, X.L. Hydrothermal synthesis of $\mathrm{CeO}_{2}$ nano-particles. J. Mater. Process. Technol. 2007, 190, 217-222. [CrossRef]

31. Ilgaz Soykal, I.; Sohn, H.; Miller, J.T.; Ozkan, U.S. Investigation of the reduction/oxidation behavior of cobalt supported on nano-ceria. Top. Catal. 2014, 57, 785-795. [CrossRef]

32. Yin, L.; Wang, Y.; Pang, G.; Koltypin, Y.; Gedanken, A. Sonochemical synthesis of cerium oxide nanoparticles-Effect of additives and quantum size effect. J. Colloid Interface Sci. 2002, 246, 78-84. [CrossRef]

33. Piumetti, M.; Andana, T.; Bensaid, S.; Russo, N.; Fino, D.; Pirone, R. Study on the CO Oxidation over Ceria-Based Nanocatalysts. Nanoscale Res. Lett. 2016, 11, 165. [CrossRef]

34. Lu, X.H.; Zheng, D.Z.; Gan, J.Y.; Liu, Z.Q.; Liang, C.L.; Liu, P.; Tong, Y.X. Porous $\mathrm{CeO}_{2}$ nanowires/nanowire arrays: Electrochemical synthesis and application in water treatment. J. Mater. Chem. 2010, 20, 7118-7122. [CrossRef]

35. Tang, W.X.; Gao, P.X. Nanostructured cerium oxide: Preparation, characterization, and application in energy and environmental catalysis. MRS Commun. 2016, 6, 311-329. [CrossRef]

36. Kovacevic, M.; Mojet, B.L.; Van Ommen, J.G.; Lefferts, L. Effects of Morphology of Cerium Oxide Catalysts for Reverse Water Gas Shift Reaction. Catal. Lett. 2016, 146, 770-777. [CrossRef]

37. Wu, Z.; Li, M.; Howe, J.; Meyer, H.M.; Overbury, S.H. Probing defect sites on $\mathrm{CeO}_{2}$ nanocrystals with well-defined surface planes by raman spectroscopy and $\mathrm{O}_{2}$ adsorption. Langmuir 2010, 26, 16595-16606. [CrossRef]

38. He, H.; Yang, P.; Li, J.; Shi, R.; Chen, L.; Zhang, A.; Zhu, Y. Controllable synthesis, characterization, and $\mathrm{CO}$ oxidation activity of $\mathrm{CeO}_{2}$ nanostructures with various morphologies. Ceram. Int. 2016, 42, 7810-7818. [CrossRef]

39. Liu, J.; Li, Y.; Zhang, J.; He, D. Glycerol carbonylation with $\mathrm{CO}_{2}$ to glycerol carbonate over $\mathrm{CeO}_{2}$ catalyst and the influence of $\mathrm{CeO}_{2}$ preparation methods and reaction parameters. Appl. Catal. A Gen. 2016, 513, 9-18. [CrossRef]

40. Tan, J.P.Y.; Tan, H.R.; Boothroyd, C.; Foo, Y.L.; He, C.B.; Lin, M. Three-dimensional structure of CeO nanocrystals. J. Phys. Chem. C 2011, 115, 3544-3551. [CrossRef]

41. Montini, T.; Melchionna, M.; Monai, M.; Fornasiero, P. Fundamentals and Catalytic Applications of $\mathrm{CeO}_{2}$-Based Materials. Chem. Rev. 2016, 116, 5987-6041. [CrossRef]

42. Tana; Zhang, M.; Li, J.; Li, H.; Li, Y.; Shen, W. Morphology-dependent redox and catalytic properties of $\mathrm{CeO}_{2}$ nanostructures: Nanowires, nanorods and nanoparticles. Catal. Today 2010, 148, 179-183. [CrossRef]

43. Yahi, N.; Menad, S.; Rodríguez-Ramos, I. Dry reforming of methane over $\mathrm{Ni} / \mathrm{CeO}_{2}$ catalysts prepared by three different methods. Green Process. Synth. 2015, 4, 479-486. [CrossRef]

44. Gonzalez-Delacruz, V.M.; Holgado, J.P.; Pereñíguez, R.; Caballero, A. Morphology changes induced by strong metal-support interaction on a Ni-ceria catalytic system. J. Catal. 2008, 257, 307-314. [CrossRef]

45. Gonzalez-Delacruz, V.M.; Ternero, F.; Pereñíguez, R.; Caballero, A.; Holgado, J.P. Study of nanostructured $\mathrm{Ni} / \mathrm{CeO}_{2}$ catalysts prepared by combustion synthesis in dry reforming of methane. Appl. Catal. A Gen. 2010, 384, 1-9. [CrossRef] 
46. Damaskinos, C.M.; Vasiliades, M.A.; Efstathiou, A.M. The effect of $\mathrm{Ti}^{4+}$ dopant in the $5 \mathrm{wt} \% \mathrm{Ni} / \mathrm{Ce}_{1-\mathrm{x}} \mathrm{Ti}_{\mathrm{x}} \mathrm{O}_{2-\delta}$ catalyst on the carbon pathways of dry reforming of methane studied by various transient and isotopic techniques. Appl. Catal. A Gen. 2019, 579, 116-129. [CrossRef]

47. Schuurman, Y.; Mirodatos, C. Uses of transient kinetics for methane activation studies. Appl Catal A 1997, 151, 305-331. [CrossRef]

48. Slagtern, A.; Schuurman, Y.; Leclercq, C.; Verykios, X.; Mirodatos, C. Specific Features Concerning the Mechanism of Methane Reforming by Carbon Dioxide over Ni/La $\mathrm{O}_{3}$ catalyst. J. Catal. 1997, 172, 118-126. [CrossRef]

49. Bobin, A.S.; Sadykov, V.A.; Rogov, V.A.; Mezentseva, N.V.; Alikina, G.M.; Sadovskaya, E.M.; Glazneva, T.S.; Sazonova, N.N.; Smirnova, M.Y.; Veniaminov, S.A.; et al. Mechanism of $\mathrm{CH}_{4}$ Dry Reforming on Nanocrystalline Doped Ceria-Zirconia with Supported Pt, Ru, Ni, and Ni-Ru. Top. Catal. 2013, 56, 958-968. [CrossRef]

50. Sadykov, V.A.; Gubanova, E.L.; Sazonova, N.N.; Pokrovskaya, S.A.; Chumakova, N.A.; Mezentseva, N.V.; Bobin, A.S.; Gulyaev, R.V.; Ishchenko, A.V.; Krieger, T.A.; et al. Dry reforming of methane over Pt/PrCeZrO catalyst: Kinetic and mechanistic features by transient studies and their modeling. Catal. Today 2011, 177, 140-149. [CrossRef]

51. Ferreira-Aparicio, P.; Marquez-Alvarez, C.; Rodriguez-Ramos, I.; Schuurman, Y.; Guerrero-Ruiz, A.; Mirodatos, C. A Transient Kinetic Study of the Carbon Dioxide Reforming of Methane over Supported Ru Catalysts. J. Catal. 1999, 184, 202-212. [CrossRef]

52. York, A.P.E.; Xiao, T.C.; Green, M.L.H.; Claridge, J.B. Methane Oxyforming for Synthesis Gas Production. Catal. Rev. 2007, 49, 511-560. [CrossRef]

53. Yuan, K.; Zhong, J.Q.; Zhou, X.; Xu, L.; Bergman, S.L.; Wu, K.; Xu, G.Q.; Bernasek, S.L.; Li, H.X.; Chen, W. Dynamic Oxygen on Surface: Catalytic Intermediate and Coking Barrier in the Modeled $\mathrm{CO}_{2}$ Reforming of $\mathrm{CH}_{4}$ on $\mathrm{Ni}$ (111). ACS Catal. 2016, 6, 4330-4339. [CrossRef]

54. Peymani, M.; Alavi, S.; Arandiyan, H.; Rezaei, M. Rational Design of High Surface Area Mesoporous Ni/CeO 2 for Partial Oxidation of Propane. Catalysts 2018, 8, 388. [CrossRef]

55. Xu, S.; Zhao, R.; Wang, X. Highly coking resistant and stable $\mathrm{Ni} / \mathrm{Al}_{2} \mathrm{O}_{3}$ catalysts prepared by W/O microemulsion for partial oxidation of methane. Fuel Process. Technol. 2004, 86, 123-133. [CrossRef]

56. Yang, H.; Whitten, J.L. Dissociative chemisorption of $\mathrm{CH}_{4}$ on Ni(111). J. Chem. Phys. 1992, 96, 5529-5537. [CrossRef]

57. Kratzer, P.; Hammer, B.; No/rskov, J.K. A theoretical study of $\mathrm{CH}_{4}$ dissociation on pure and gold-alloyed Ni(111) surfaces. J. Chem. Phys. 2002, 105, 5595-5604. [CrossRef]

58. Papadopoulou, C.; Matralis, H.; Verykios, X.E. Utilization of Biogas as a Renewable Carbon Source: Dry Reforming of Methane. In Catalysis for alternative energy generation; Springer: New York, NY, USA, 2012; pp. 57-126.

59. Helveg, S.; Lopez-Cartes, C.; Sehested, J.; Hansen, P.L.; Clausen, B.S.; RostrupNielsen, J.R.; Abild-Pedersen, F.; Nørskov, J.K. Atomic-scale imaging of carbon nanofibre growth. Nature 2004, 427, 426-429. [CrossRef]

60. Toebes, M.L.; Bitter, J.H.; van Dillen, A.J.; de Jong, K.P. Impact of the structure and reactivity of nickel particles on the catalytic growth of carbon nanofibers. Catal. Today 2002, 76, 33-42. [CrossRef]

61. Liu, J.X.; Zhang, B.Y.; Chen, P.P.; Su, H.Y.; Li, W.X. CO Dissociation on Face-Centered Cubic and Hexagonal Close-Packed Nickel Catalysts: A First-Principles Study. J. Phys. Chem. C 2016, 120, 24895-24903. [CrossRef]

62. Choudhary, T.V.; Goodman, D.W. Methane activation on Ni and Ru model catalysts. J. Mol. Catal. A Chem. 2000, 163, 9-18. [CrossRef]

63. Abild-Pedersen, F.; Nørskov, J.K.; Rostrup-Nielsen, J.R.; Sehested, J.; Helveg, S. Mechanisms for catalytic carbon nanofiber growth studied by ab initio density functional theory calculations. Phys. Rev. B 2006, 73, 115419. [CrossRef]

64. Wang, X.; Yuan, Q.; Li, J.; Ding, F. The transition metal surface dependent methane decomposition in graphene chemical vapor deposition growth. Nanoscale 2017, 9, 11584-11589. [CrossRef]

65. Yang, K.; Zhang, M.; Yu, Y. Theoretical insights into the effect of terrace width and step edge coverage on CO adsorption and dissociation over stepped Ni surfaces. Phys. Chem. Chem. Phys. 2017, 19, 17918-17927. [CrossRef]

66. Beebe, T.P.; Goodman, D.W.; Kay, B.D.; Yates, J.T. Kinetics of the activated dissociative adsorption of methane on the low index planes of nickel single crystal surfaces. J. Chem. Phys. 1987, 87, 2305-2315. [CrossRef] 
67. Wang, S.G.; Cao, D.B.; Li, Y.W.; Wang, J.; Jiao, H. Chemisorption of $\mathrm{CO}_{2}$ on nickel surfaces. J. Phys. Chem. B 2005, 109, 18956-18963. [CrossRef]

68. Burghgraef, H.; Jansen, A.P.J.; van Santen, R.A. Methane activation and dehydrogenation on nickel and cobalt: A computational study. Surf. Sci. 1995, 324, 345-356. [CrossRef]

69. Wind, T.L.; Falsig, H.; Sehested, J.; Moses, P.G.; Nguyen, T.T.M. Comparison of mechanistic understanding and experiments for CO methanation over nickel. J. Catal. 2016, 342, 105-116. [CrossRef]

70. Engbæk, J.; Lytken, O.; Nielsen, J.H.; Chorkendorff, I. CO dissociation on Ni: The effect of steps and of nickel carbonyl. Surf. Sci. 2008, 602, 733-743. [CrossRef]

71. Arevalo, R.L.; Aspera, S.M.; Escaño, M.C.S.; Nakanishi, H.; Kasai, H. Tuning methane decomposition on stepped Ni surface: The role of subsurface atoms in catalyst design. Sci. Rep. 2017, 7, 13963. [CrossRef]

72. Schouten, F.C.; Gijzeman, O.L.J.; Bootsma, G.A. Reaction of methane with nickel single crystal surfaces and the stability of surface nickel carbides. Bull. Sociétés Chim. Belges 1979, 88, 541-547. [CrossRef]

73. Vasiliades, M.A.; Damaskinos, C.M.; Kyprianou, K.K.; Kollia, M.; Efstathiou, A.M. The effect of Pt on the carbon pathways in the dry reforming of methane over $\mathrm{Ni}-\mathrm{Pt} / \mathrm{Ce}_{0.8} \mathrm{Pr}_{0.2} \mathrm{O}_{2-\delta}$ catalyst. Catal. Today 2019. [CrossRef]

74. Li, B.; Zhang, S. Methane reforming with $\mathrm{CO}_{2}$ using nickel catalysts supported on yttria-doped SBA-15 mesoporous materials via sol-gel process. Int. J. Hydrogen Energy 2013, 38, 14250-14260. [CrossRef]

75. Polychronopoulou, K.; Costa, C.N.; Efstathiou, A.M. The steam reforming of phenol reaction over supported-Rh catalysts. Appl. Catal. A Gen. 2004, 272, 37-52. [CrossRef]

76. Christou, S.Y.; Costa, C.N.; Efstathiou, A.M. A Two-Step Reaction Mechanism of Oxygen Release from $\mathrm{Pd} / \mathrm{CeO}_{2}$ : Mathematical Modelling Based on Step Gas Concentration Experiments. Top. Catal. 2004, 30, 325-331. [CrossRef]

(C) 2019 by the authors. Licensee MDPI, Basel, Switzerland. This article is an open access article distributed under the terms and conditions of the Creative Commons Attribution (CC BY) license (http://creativecommons.org/licenses/by/4.0/). 